\title{
A reprodução simbólica das desigualdades entre mulheres e homens no Brasil
}

\author{
Letícia Maria Schabbach ${ }^{1}$ id
}

\begin{abstract}
Este artigo trata de representações coletivas (Durkheim, 1996) ou representações sociais (Moscovici, 2003) com recorte de gênero (Scott, 1986) sobre assuntos concernentes aos espaços público e privado (Saffioti, 1999; Fougeyrollas-Schwebel, 2009). A partir de compilação e análise de dados da Pesquisa Nacional "Mulheres brasileiras e gênero nos espaços público e privado" (Fundação Perseu Abramo, 2010), almejou-se: a) conhecer a difusão geral das representações; b) comparar as opiniões femininas e masculinas, em suas semelhanças e diferenças. As representações reforçam o papel da mulher como encarregada do trabalho reprodutivo e não remunerado e do homem como provedor do lar e atuante no espaço público, como demonstra, por exemplo, a desconfiança manifestada pelos entrevistados sobre a capacidade político-administrativa das mulheres e sobre a habilidade masculina em executar tarefas domésticas.
\end{abstract}

Palavras-chave: representações sociais; violência simbólica; gênero; espaço público; espaço privado

\section{Introdução}

Este artigo analisa as representações sociais de mulheres e homens como elementos simbólicos que perpetuam as desigualdades de gênero, tendo como escopo empírico os microdados da Pesquisa Nacional "Mulheres brasileiras e gênero nos espaços público e privado", doravante Pesquisa Nacional Mulheres Brasileiras (PNMB). Trata-se de um survey nacional aplicado pela Fundação Perseu Abramo e pelo Serviço Social do Comércio (Sesc) em agosto de $2010^{3}$. O levantamento abarcou os seguintes assuntos: a) percepção de ser mulher, machismo e feminismo; b) divisão sexual do trabalho e tempo

\footnotetext{
${ }^{1}$ Departamento de Sociologia e Programas de Pós-Graduação em Sociologia e Políticas Públicas. Universidade Federal do Rio Grande do Sul. Porto Alegre (RS), Brasil. E-mail: <leticiams65@gmail.com>.

2 Agradeço aos/às pareceristas anônimos(as) as valiosas críticas e sugestões que foram essenciais ao aprimoramento do artigo.

3 O levantamento teve amostragem probabilística, margem de erro entre dois e quatro pontos percentuais, $95 \%$ de intervalo de confiança, e contou com a aplicação de questionário, em agosto de 2010, a 2.365 mulheres e 1.188 homens de 15 anos de idade ou mais, residentes em mais de 100 municípios de 25 estados brasileiros, na área rural e urbana. O banco de dados da pesquisa foi disponibilizado pelo Consórcio de Informações Sociais em <http://www.nadd.prp.usp.br/cis/DetalheBancoDados.aspx?cod=B454\&lng=ptbr>. Acesso em: 27 jun. 2020.
} 
livre; c) corpo, mídia e sexualidade; d) saúde reprodutiva e aborto; e) violência doméstica; f) democracia, mulher e política.

O artigo pretende, por um lado, examinar a difusão generalizada (entre mulheres e homens) de representações sociais sobre a participação da mulher na política institucional e como governante; sobre quem deve recair a responsabilidade pelo trabalho assalariado, pelo sustento da casa e pela organização do trabalho doméstico, e, adicionalmente, a respeito de questões sobre a possibilidade de voto em candidato homossexual, que apoia a legalização do aborto ou que defende a união civil homoafetiva; e, por outro, comparar as opiniões femininas e masculinas sobre tais assuntos. A magnitude das diferenças entre as respostas femininas e masculinas foi testada cruzandose as variáveis e suas respectivas categorias com a variável sexo ${ }^{4}$. Dessa forma, inicialmente cabe uma advertência: embora a pesquisa nacional acima referida contenha em seu título o termo "gênero" e o presente artigo discuta mais adiante esse conceito, as análises das informações restringiram-se à diferenciação binária entre mulheres e homens, identificada no instrumento de pesquisa pelo quesito "sexo", sem considerar outras formas de dominação presentes nos atravessamentos de raça, classe social, identidade de gênero etc.

A seguir, ainda nesta Introdução, são examinados os conceitos que embasam o estudo: dominação, violência simbólica e representações sociais. Na seção subsequente, "A organização social de gênero e a dualidade público versus privado", são abordadas as manifestações da organização social de gênero nos espaços privado e público, a partir das quais foram organizados os resultados da pesquisa. Posteriormente, em "Metodologia", são apresentadas as características gerais da PNMB e os procedimentos metodológicos utilizados. Depois, em "Análise das representações de mulheres e homens", são analisados os resultados no tocante às representações de mulheres e homens sobre questões de seu cotidiano em ambos os espaços. Por fim, na "Conclusão", são destacados os principais achados do estudo, cotejando-os com os aportes teóricos pertinentes.

Para Weber (1969), uma relação de dominação é a probabilidade de encontrar obediência a determinado mandato ou ordem, reunindo dois elementos centrais: a) a reciprocidade ou a adequação das ações à expectativa de que os outros reagirão de forma mais ou menos previsível; b) o consentimento dos subordinados em obedecer, devido a uma série de motivos, isolados ou combinados: interesses (o cotejamento das utilidades versus os inconvenientes), crença na legalidade, costume (hábito cego de um comportamento inveterado) ou afeto (inclinação pessoal). A relação deixará de existir quando não houver mais a referência recíproca das ações entre as partes envolvidas:

Consideramos como "dominação" um estado de coisas pelo qual uma vontade manifesta (mandato) do dominador ou dos dominadores influi sobre os atos

\footnotetext{
4 Para a organização dos dados e a execução dos procedimentos estatísticos, foi utilizado o software

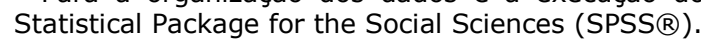


de outros (do dominado ou dos dominados), de tal modo que em um grau socialmente relevante estes atos têm lugar como se os dominados tivessem adotado, por si mesmos e como máxima de sua ação, o conteúdo do mandato (obediência) (Weber, 1969, p. 699).

É um consenso dentro das ciências sociais que os vários tipos de dominação econômica, política, cultural, geracional, étnico-racial, de gênero - englobam uma dimensão simbólica que cimenta e reproduz a subordinação. Expressões como ideologia (Marx, 2008), discurso como instrumento de saber-poder (Foucault, 1987, 1988), poder simbólico e violência simbólica (Bourdieu, 1989, 1999) e símbolos, conceitos normativos e representações sociais vinculadas ao gênero (Scott, 1986) demarcam as formas simbólicas inerentes aos processos sociais.

Uma das maneiras de apreendê-las é por meio do estudo das representações sociais, as quais, enquanto faladas, escritas ou simbolizadas graficamente, referem-se às percepções de um indivíduo ou grupo social sobre algum assunto. Elas permitem analisar determinada realidade segundo a perspectiva dos sujeitos que as emitem e/ou as replicam, não sendo "nem falsas e nem verdadeiras, mas a matéria-prima do fazer sociológico" (Porto, 2010, p. 68).

Embora sob outras denominações, as teorias clássicas da sociologia incorporam as representações como um aspecto central do conhecimento; por exemplo, em Durkheim, as maneiras de pensar como fato social; em Marx, a articulação entre as relações de produção e as formas ideológicas; em Weber, a compreensão do mundo por meio dos significados que os indivíduos atribuem à ação social. Entretanto, foi o sociólogo francês que mais diretamente tratou da temática das representações, a ponto de não restringir o fato social ao agir físico, mas como: "(...) toda maneira de agir física ou não, suscetível de exercer sobre o indivíduo uma coerção exterior; ou então, ainda, que é geral na extensão de uma sociedade dada, apresentando uma existência própria, independente das manifestações individuais que possa ter" (Durkheim, 1974, p. 11).

Existem, segundo esse autor, três conjuntos diferentes de fatos sociais: a) as maneiras de ser já cristalizadas, como as regras jurídicas e morais, os dogmas religiosos, os sistemas e instituições, a linguagem escrita; b) as formas de agir encontradas nas correntes sociais e de opinião, bem como os movimentos coletivos que aparecem em certas épocas e contextos, como o casamento, as correntes suicidógenas, as taxas de natalidade etc.; c) as formas de pensar, ou as representações coletivas, que se distinguem das individuais, pois, enquanto estas se associam às sensações, ações e reações dos elementos nervosos dos indivíduos, aquelas contemplam as concepções religiosas e crenças morais e significam "a ideia que ela [a sociedade] faz de si mesma" (Durkheim, 1996, p. 467), sendo veiculadas por uma "intelectualidade muito particular, infinitamente mais rica e mais complexa que a do indivíduo" (Durkheim, 1996, p. XXIII).

Contemporaneamente, as correntes teóricas construtivistas e pós-estruturalistas confrontaram a separação entre discurso e prática presente em Marx (infraestrutura 
material versus superestrutura ideológica) e certa dicotomia nos termos propostos por Durkheim (formas de agir versus formas de pensar). Entre elas, cita-se o legado de Foucault (1987), especialmente os seus conceitos de formação discursiva e discurso; e de Bourdieu (1989), com destaque para o conceito de poder simbólico.

Em seu livro Arqueologia do saber, ao apresentar o conceito de formação discursiva como o domínio das "coisas ditas", das "regularidades discursivas", Foucault atribui aos discursos a característica de práticas sociais "que formam sistematicamente os objetos de que falam", incluindo a produção de indivíduos e identidades diferenciadas. Além disso, para o autor, os sistemas discursivos representam mecanismos de saber-poder ou "dispositivos" inscritos em uma lógica de dominação (Foucault, 1987, p. 56; Poster, 1987).

Bourdieu (1989), por sua vez, concebe o poder simbólico como a possibilidade de impor determinado discurso ou visão sobre o mundo, dentro de um espaço de disputas muito desiguais em torno das classificações do mundo social, que resultam na incorporação e na legitimação de certas categorias (dominantes), tanto pelos emitentes/defensores quanto pelos receptores/opositores:

O poder simbólico como poder de constituir o dado pela enunciação, de fazer ver e fazer crer, de confirmar ou de transformar a visão do mundo e, deste modo, a ação sobre o mundo, portanto, o mundo; poder quase mágico que permite obter o equivalente daquilo que é obtido pela força (física ou econômica), graças ao efeito de mobilização, só se exerce se for reconhecido, quer dizer, ignorado como arbitrário. (...) é, com efeito, esse poder invisível o qual só pode ser exercido com a cumplicidade daqueles que não querem saber que Ihe estão sujeitos ou mesmo que o exercem (Bourdieu, 1989, p. 14 e 8).

Dentro das lutas simbólicas, as representações e os discursos têm efeito performativo, ao constituírem sistematicamente os objetos, os sujeitos e as realidades nomeadas (o efeito de worldmaking, conforme Bourdieu, 1989, p. 237).

Por outro lado, o conceito de violência simbólica envolve a imposição de signos e valores culturais dominantes, que são, com frequência, depreciativos dos grupos sociais dominados. Todavia, esses termos são incorporados, de maneira nem sempre consciente ou deliberada, como se fossem naturais, e não históricos e sociais. Trata-se de um fenômeno menos visível do que as manifestações ostensivas de violência ${ }^{5}$ e que raramente é percebido enquanto tal.

Nota-se que o conceito de violência simbólica é muito próximo ao de poder simbólico. Em específico, ela é considerada um tipo "suave, insensível, invisível a suas próprias vítimas, que se exerce essencialmente pelas vias puramente simbólicas da

\footnotetext{
5 Para Bourdieu (1999), a violência simbólica não se opõe à física, estando ligada a ela. Nesse mesmo sentido, Wieviorka (1999) ressalta que não se pode opor a violência simbólica à concreta, pois, apesar de analiticamente diferentes, elas sempre aparecem combinadas nas situações e processos sociais.
} 
comunicação e do conhecimento, ou, mais precisamente, do desconhecimento, do reconhecimento ou, em última instância, do sentimento" (Bourdieu, 1999, p. 7-8). Nesse sentido, ela envolve, por um lado, a aceitação tácita dos instrumentos de cognição e significação do mundo social (representações sociais, discursos, linguagem, hexis corporal etc.) e, por outro, o desconhecimento de sua origem e suportes. Portanto, "A destruição deste poder de imposição simbólico radicado no desconhecimento supõe a tomada de consciência do arbitrário, quer dizer, a revelação da verdade objetiva e o aniquilamento da crença" (Bourdieu, 1989, p. 15, nota de rodapé 8).

Além das ciências sociais, as representações passaram a ser debatidas pela psicologia social a partir da década de 1960, com a substituição do adjetivo "coletivas" (aposto por Durkheim) por "sociais". Em 1961 foi publicada a obra do psicólogo romeno Serge Moscovici La psychanalyse: son image et son public (Moscovici, 2003), a partir da qual a temática foi difundida para outras áreas que incorporaram as representações como ferramenta de conhecimento da realidade social. Citam-se, como autores referenciais dessa confluência, além do próprio Moscovici, Jodelet (1985, 1989), Bauer (1994), Jovchelovitch (1994, 2011), Spink (1993), Minayo (1994), Vala (2000), Porto (2006, 2010), Charaudeau (2013), entre outros.

O próprio Moscovici (2003, p. 21) define as representações sociais como:

(...) um sistema de valores e práticas, com uma dupla função: primeiro, estabelecer uma ordem que possibilitará às pessoas orientar-se em seu mundo material e social e controlá-lo; e, em segundo lugar, possibilitar que a comunicação seja possível entre os membros de uma comunidade, fornecendo-Ihes um código para nomear e classificar, sem ambiguidade, os vários aspectos de seu mundo e da história individual e social.

A partir dessa produção mais recente e interdisciplinar, destacam-se, a seguir, alguns entendimentos comuns sobre representações sociais:

a) Embora expressas por indivíduos, são produzidas socialmente, variando conforme o contexto, o grupo social e a posição ocupada pelos sujeitos nos diferentes espaços. b) Configuram e fortalecem grupos e identidades grupais, prescrevem o que é permitido ou proibido e quais valores, normas e visões de mundo podem ser partilhadas.

c) São construções que emergem nas relações entre os agentes (individuais e coletivos) e nas lutas simbólicas em torno das definições do social. Dessa forma, elas criam, manifestam, mantêm e atualizam as relações de poder.

Ao considerar que as representações (e os discursos) são veiculadas de diferentes maneiras - elementos informativos, cognitivos, ideológicos, normativos, crenças, valores, atitudes, opiniões, imagens (Jodelet, 1989; Spink, 1993) -, defendo, neste artigo, a 
possibilidade de apreendê-las em suas várias manifestações, tais como: narrativas faladas, registros escritos de opiniões e atitudes, imagens e signos.

\section{A organização social de gênero e a dualidade público versus privado}

O conceito de gênero, difundido em meados da década de 1980, foi rapidamente incorporado pelo movimento feminista e por pesquisadoras acadêmicas em todo o mundo, constituindo-se, desde então, em categoria analítica e política ${ }^{6}$. Uma das principais referências sobre esse termo é a da historiadora norte-americana Joan Wallach Scott, que, em artigo publicado originalmente em 1986, esclarece:

Minha definição de gênero tem duas partes e diversos subconjuntos, que estão inter-relacionados, mas devem ser analiticamente diferenciados. O núcleo da definição repousa numa conexão integral entre duas proposições: (1) o gênero é um elemento constitutivo de relações sociais baseadas nas diferenças percebidas entre os sexos e (2) o gênero é uma forma primária de dar significado às relações de poder. (...) Seria melhor dizer o gênero é um campo primário no interior do qual, ou por meio do qual, o poder é articulado (Scott, 1986, p. 86 e 88).

Defendendo uma perspectiva relacional, a autora enfatiza que os sujeitos são constituídos não de forma isolada, mas recíproca. Além disso, o seu conceito de poder baseia-se em Foucault $(1987,1988)$, visto como descentrado e variável, "constelações dispersas de relações desiguais, discursivamente constituídas em 'campos de força' sociais" (Scott, 1986, p. 86).

Scott (1986) ressalta, ainda, que gênero abrange quatro elementos interrelacionados: a) os símbolos culturalmente disponíveis que evocam representações simbólicas por vezes contraditórias (por exemplo, Eva, pecadora, versus Maria, santa); b) os conceitos normativos que expressam interpretações dos significados dos símbolos e que, sob a forma de uma oposição binária fixa, estão presentes em doutrinas religiosas, educativas, científicas, políticas ou jurídicas; c) uma concepção de política associada às instituições e à organização social (que transcende o parentesco, abarcando também o mercado de trabalho, a economia, a educação, a organização pública, o sistema político etc.); d) identidades subjetivas e generificadas construídas historicamente, dentro de movimentos que reúnem atividades, organizações e representações sociais específicas.

\footnotetext{
6 Nesse mesmo período o movimento feminista discutia as interseccionalidades e a pluralidade das experiências das mulheres (articulação com etnia/raça, classe, idade, religião etc.), temáticas tributárias do feminismo negro insurgente na década de 1970. Posteriormente, surgiram as abordagens pósestruturalistas, que, em síntese, buscavam compreender as construções de gênero privilegiando o particular e específico em detrimento das leis gerais; não consideravam imutáveis os papéis e as relações sociais de gênero (porquanto históricas); rejeitavam o determinismo biológico e enfatizavam que o gênero está presente em todos os aspectos da experiência humana (Conceição, 2009).
} 
Ainda que resultem de processos históricos, as configurações de gênero não são imutáveis, pois:

No interior desses processos e estruturas, há espaço para um conceito de agência humana, concebida como a tentativa (pelo menos parcialmente racional) para construir uma identidade, uma vida, um conjunto de relações, uma sociedade estabelecida dentro de certos limites e dotada de uma linguagem - uma linguagem conceitual que estabeleça fronteiras e contenha, ao mesmo tempo, a possibilidade da negação, da resistência, da reinterpretação e permita o jogo da invenção metafórica e da imaginação (Scott, 1986, p. 86).

Assim, na visão de Scott (1986), a mudança dependerá de ações políticas e simbólicas, o que remete ao nexo dialético entre poder e resistência enfatizado por Foucault. Segundo o autor (Foucault, 1984, p. 242): "não há relação de poder sem resistência, sem escapatória ou fuga, sem eventual reviravolta; toda relação de poder implica, portanto, ao menos de modo virtual, uma estratégia de luta, sem que, entretanto, essas duas estratégias venham a se sobrepor, a perder sua especificidade ou a se confundir". Nesse sentido, as relações de poder sempre engendram uma "multiplicidade de pontos de resistência" (Foucault, 1988, p. 90).

Com inspiração no supracitado conceito, adoto neste artigo o termo "organização social de gênero" para nomear o conjunto de estruturas de dominação marcadas por assimetrias de gênero, encontradas em todos os espaços sociais (conjugalidade, família, educação, trabalho, religião, Estado, mídia etc. $)^{7}$. Essas estruturas podem ser encontradas nos espaços público e privado de relações sociais, cuja separação e aparente dicotomia não são um consenso na literatura sobre gênero. Nesse sentido, Biroli (2014) apresenta três posições a esse respeito, citando autoras que: a) consideram essa dicotomia uma ficção, uma vez que as desigualdades produzidas em ambos os espaços se interconectam; b) definem o privado como o espaço da ética do cuidado e da gestão dos afetos, que pode impactar a esfera pública; c) caracterizam o privado como lugar de dominação e, ao mesmo tempo, de tomada de consciência, enquanto elemento necessário à luta das mulheres em prol da autonomia.

Neste artigo são examinados em separado o espaço público e o espaço privado, reconhecendo-se a sua diferenciação, pois em cada um deles as desigualdades entre mulheres e homens são reproduzidas dentro de dinâmicas e processos peculiares. Tais assimetrias perduram mesmo com a melhoria da condição feminina quanto: à maior inserção no mercado de trabalho formal (inclusive em altas posições hierárquicas e em profissões tradicionalmente percebidas como masculinas); à maior escolaridade e a

\footnotetext{
7 Com a utilização desse conceito optou-se por não dialogar, neste artigo, com as expressões "patriarcado" (Pateman, 1993; Saffioti, 2004; Castro, 2012) e "dominação masculina" (Bourdieu, 1999). Não obstante, ressalta-se a sua relevante contribuição ao debate sobre gênero.
} 
mudanças nas instituições escolares por conta da maior presença feminina; à maior participação masculina nas tarefas domésticas; ao advento de novas configurações familiares e de novos modelos de sexualidade e de conjugalidade; à ampliação das garantias jurídicas (como o direito ao divórcio e às leis protetivas); à implementação de políticas sociais direcionadas às mulheres etc.

O mercado de trabalho ilustra bem essa realidade. Segundo dados da Pesquisa Nacional por Amostra de Domicílios (PNAD) Contínua Trimestral, do primeiro trimestre de 2019 (IBGE, 2019b), as mulheres brasileiras de 14 ou mais anos de idade ocupadas representavam $52,4 \%$ da população feminina, contra $47,6 \%$ entre os homens. Todavia, há diferenças no rendimento médio nominal para o conjunto de trabalhos realizados no mês de referência: $R \$ 2.213,00$ para elas contra $R \$ 2.725,00$ para eles. Esse fato ilustra o princípio de hierarquização da divisão sexual do trabalho apontado por Hirata et al. (2009), que explica o maior valor social atribuído ao trabalho masculino.

Na esfera da política (politics) também se verifica a ampliação da participação feminina, incentivada, entre outros dispositivos, pela lei das cotas partidárias (Brasil, 1997), a qual prevê um mínimo de 30\% e um máximo de $70 \%$ das vagas de partidos ou coligações para candidaturas de cada sexo. No caso das mulheres, entretanto, o percentual mínimo (30\%) é raramente atingido; além disso, quando eleitas para o Legislativo federal brasileiro, elas alcançam apenas $15 \%$ do total de representantes, contra $31 \%$ na América Latina e Caribe e 24\% em nível mundial (Brasil, 2018; World Bank Group, 2018). No caso do Poder Executivo, nas eleições de 2016 as mulheres atingiram 13,1\% do total de candidatos(as) a prefeito(a) e 32,5\% dos candidatos(as) a vereador(a), tendo sido eleitas 635 prefeitas $(11,6 \%$ do total de prefeitos(as)) e 7.820 vereadoras $(13,5 \%$ do total de vereadores(as)) (Brasil, 2016).

Na visão de Saffioti (1999, p. 86), as mulheres não dominam os macropoderes, já que foram historicamente deles alijadas; em contrapartida, elas manejam bem os micropoderes. Mesmo reconhecendo as conquistas femininas quanto aos direitos e liberdades formais, Bourdieu (1999, p. 52), por sua vez, ressalta a permanência de uma "agorafobia socialmente imposta" enfrentada pelas mulheres, que faz com que a maioria delas continue a rejeitar e a se autoexcluir dos lugares públicos e da arena política. Miguel (2010) salienta que as mulheres que conseguem ingressar no Parlamento são alocadas em posições inferiores, nas quais passam a lidar com temáticas pouco valorizadas, como as relativas a família, educação ou assistência social. Enquanto isso, a hard politics (que abrange economia, infraestrutura, gestão do Estado etc.) é hegemonizada pelos homens. Essa distinção decorre dos estereótipos inerentes aos papéis sociais de gênero, de difícil modificação, pois: "o acesso à franquia eleitoral é uma condição necessária, mas nem de longe suficiente, para se chegar às esferas de exercício do poder político" (Miguel, 2010, p. 25).

Por sua vez, o espaço privado, que abarca as relações pessoais íntimas, conjugais e familiares, é o lócus do trabalho reprodutivo cuja responsabilidade recai majoritariamente 
sobre a mulher, o que acaba repercutindo nas oportunidades de acesso ao mercado laboral e de desempenho profissional. As atividades realizadas nesse espaço costumam ser mapeadas pelas chamadas pesquisas de usos do tempo ${ }^{8}$, as quais, ao tratarem das diferenças de gênero existentes nas esferas produtiva e privada, pressupõem que "são distintas as modalidades de inserção de homens e mulheres em cada uma dessas esferas, conduzindo a processos específicos de individuação" (Fougeyrollas-Schwebel, 2009, p. 258).

Para Fontoura e Araújo (2016), a distribuição desigual das atividades nas 24 horas diárias entre homens e mulheres, existente na maioria dos países, especialmente a separação entre trabalho produtivo/remunerado e reprodutivo/não remunerado, é um obstáculo para a igualdade de gênero. Conforme Barajas (2016, p. 22), o trabalho doméstico e de cuidados está situado fora do escopo da macroeconomia e até mesmo do âmbito das políticas públicas:

O trabalho doméstico e de cuidados abarca as atividades de manutenção do lar (cozinhar, limpar, administrar) e atividades de cuidado direto, ou seja, de pessoa a pessoa (idosos, crianças pequenas e outras pessoas dependentes, como doentes crônicos ou pessoas com deficiência). Embora esse trabalho seja fundamental para o funcionamento das famílias; o bem-estar de seus membros; a evolução do mercado, em função da reprodução social; e, ainda, a coesão social e familiar, o trabalho doméstico e de cuidados costuma permanecer invisível para a economia. De fato, encontra-se praticamente ausente dos modelos macroeconômicos de onde proveem as políticas públicas e seu financiamento.

As mudanças ocorridas no Brasil nas últimas décadas - na composição do mercado de trabalho, na estrutura demográfica e nas relações familiares e afetivas - abalaram o modelo tradicional que concebe o homem como o provedor da casa e a mulher como a única responsável pelo trabalho doméstico não remunerado. Entretanto, mesmo quando provedora do lar e estando empregada integral ou parcialmente, a mulher não se desvincula dos encargos reprodutivos, continuando a executar as tarefas domésticas e de cuidado. Isso gera um aumento da carga horária total do trabalho feminino (remunerado e não remunerado), configurando o que comumente se denomina de dupla ou tripla jornada. Em contrapartida, embora estejam participando mais dos afazeres domésticos, os homens não acompanharam o ritmo e a intensidade da presença feminina no mercado laboral (Bandeira e Preturlan, 2016).

De acordo com Bandeira e Preturlan (2016) e Dedecca (2012), essa situação varia de acordo com a condição econômica, pois, enquanto as trabalhadoras de classe média

\footnotetext{
8 Conforme Barajas (2016), as pesquisas sobre usos do tempo buscam medir e analisar: a) o trabalho doméstico e voluntário não remunerado de mulheres e homens no lar, na comunidade e em associações e organizações sem fins lucrativos; b) o trabalho remunerado no setor informal (inclusive o emprego doméstico); c) a inter-relação entre as atividades econômicas e não econômicas femininas e masculinas.
} 
podem contar, muitas vezes, com uma rede de outras mulheres - empregadas domésticas, babás, diaristas e cuidadoras -, as mulheres pobres cumprem uma jornada total de trabalho mais extensa, tanto em relação aos homens pobres quanto às mulheres dos estratos superiores.

A maior dedicação feminina ao trabalho reprodutivo e de cuidados é evidenciada pelos resultados da PNAD (IBGE, 2019a): em geral, 87\% da população (147,5 milhões de brasileiros) com 14 ou mais anos de idade realizaram afazeres domésticos e/ou de cuidados de moradores ou familiares em 2018; todavia, a participação delas foi de $93 \%$ contra $80 \%$ da deles. Quanto à carga horária média semanal despendida nas atividades de casa, para as mulheres ela atingiu 21 horas e para os homens 11 horas. Essa diferença manteve-se entre os ocupados, perfazendo, respectivamente, 19 horas e 10 horas semanais.

Para os propósitos deste artigo, a distinção entre o espaço público e o privado foi utilizada na organização das variáveis correspondentes às representações sociais de mulheres e de homens, bem como na exposição dos resultados encontrados.

\section{Metodologia}

A segunda versão da PNMB $^{9}$ foi realizada em agosto de 2010 em um contexto de ampliação da atuação feminina na arena pública (mercado de trabalho, política, educação, cultura etc.) e dos direitos das mulheres, juntamente com a criação de organismos públicos e programas governamentais voltados a esse grupo social. Merecem destaque: a criação de delegacias de polícia e serviços especializados, a implantação da Lei Maria da Penha (Brasil, 2006), que criminalizou a violência contra as mulheres, a criação da Secretaria Especial de Políticas para as Mulheres em 2003 (transformada em Ministério em agosto de 2010 e, posteriormente, incorporada ao Ministério das Mulheres, da Igualdade Racial e dos Direitos Humanos, em 2015) e a elaboração dos planos nacionais de políticas para mulheres (Plano Nacional, em 2004, e II Plano Nacional, em 2008). É importante destacar, ainda, que na época da pesquisa estava ocorrendo a campanha para as eleições presidenciais, com a participação de duas candidatas (em um total de nove), Marina Silva e Dilma Rousseff, esta tendo sido eleita como a primeira presidente da história brasileira.

Os resultados gerais do survey (2010), apresentados por Venturi e Godinho $(2013)^{10}$, revelam que, na opinião da maioria das mulheres entrevistadas $(74 \%)$, a situação feminina havia melhorado. Porém, $67 \%$ delas concordaram com a existência do machismo e $18 \%$ afirmaram ter sido vítimas de violência por algum homem.

\footnotetext{
${ }^{9}$ Em 2001 foi realizada a primeira versão do survey, que não incluiu os homens.

10 Os resultados encontram-se disponíveis em: < https://fpabramo.org.br/publicacoes/publicacao/pesquisamulheres-brasileiras-e-genero-nos-espacos-publico-e-privado-2010/>. Acesso em: 27 jun. 2020.
} 
A seguir, apresenta-se a metodologia empregada na análise das representações de mulheres e de homens sobre temas atinentes às relações de gênero nos espaços público e privado a partir da pesquisa supracitada (Fundação Perseu Abramo e Sesc, 2010).

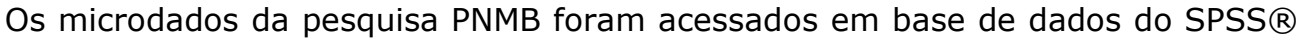
que continha 3.194 casos e 297 variáveis. Preliminarmente, apresentam-se, na Tabela 1, algumas características do conjunto de respondentes: $69 \%$ eram mulheres e $31 \%$, homens; as faixas etárias mais frequentes eram as de 25 a 34 (22\%), de 35 a 44 e de 45 a 59 (19\% cada), e de 18 a 24 anos de idade (18\%); a maioria (68\%) possuía um ou mais filhos; $64 \%$ passaram a maior parte de sua vida na cidade (contra $33 \%$ no campo); $47 \%$ detinham renda familiar até dois salários mínimos e $35 \%$, mais de dois a cinco salários mínimos; 53\% exerciam atividade remunerada, $18 \%$ eram donas de casa e $12 \%$, aposentados. Entre os(as) trabalhadores(as), 39\% eram assalariados(as) com carteira assinada, 20\% trabalhavam por conta própria, 14\% eram funcionários(as) públicos(as) e $13 \%$, assalariados(as) sem carteira assinada.

Tabela 1

Características dos respondentes

\begin{tabular}{|c|c|c|c|}
\hline Atributos & Categorias & $\begin{array}{c}N^{\circ} \\
\text { absolutos }\end{array}$ & $\begin{array}{c}\% \\
\text { respostas }\end{array}$ \\
\hline \multirow{2}{*}{$\begin{array}{l}\text { Sexo } \\
n=3.194\end{array}$} & Mulheres & 2.204 & 69 \\
\hline & Homens & 990 & 31 \\
\hline \multirow{6}{*}{$\begin{array}{l}\text { Faixas etárias } \\
\mathrm{n}=3.194\end{array}$} & 15 a 17 anos & 237 & 07 \\
\hline & 18 a 24 anos & 561 & 18 \\
\hline & 25 a 34 anos & 718 & 22 \\
\hline & 35 a 44 anos & 612 & 19 \\
\hline & 45 a 59 anos & 615 & 19 \\
\hline & 60 ou mais anos & 451 & 14 \\
\hline \multirow{2}{*}{$\begin{array}{l}\text { Filhos } \\
n=2.580\end{array}$} & Com filhos (um ou mais) & 1.742 & 68 \\
\hline & Sem filhos & 738 & 32 \\
\hline \multirow{3}{*}{$\begin{array}{l}\text { Onde passou a } \\
\text { maior parte da } \\
\text { vida } \\
n=3.187\end{array}$} & Cidade & 2.047 & 64 \\
\hline & Campo & 1.046 & 33 \\
\hline & Ambos ou meio a meio & 94 & 03 \\
\hline \multirow{7}{*}{$\begin{array}{l}\text { Renda familiar } \\
n=2.826\end{array}$} & Até 1 salário mínimo & 508 & 18 \\
\hline & Mais de 1 a 2 salários mínimos & 815 & 29 \\
\hline & Mais de 2 a 5 salários mínimos & 985 & 35 \\
\hline & Mais de 5 a 10 salários mínimos & 371 & 13 \\
\hline & Mais de 10 a 20 salários mínimos & 109 & 04 \\
\hline & Mais de 20 salários mínimos & 31 & 01 \\
\hline & Não tem renda & 07 & 00 \\
\hline
\end{tabular}




\begin{tabular}{|c|c|c|c|}
\hline Atributos & Categorias & $\begin{array}{c}\mathbf{N}^{\circ} \\
\text { absolutos }\end{array}$ & $\begin{array}{c}\% \\
\text { respostas } \\
\end{array}$ \\
\hline \multirow{6}{*}{$\begin{array}{l}\text { Trabalho } \\
\mathrm{n}=3.192\end{array}$} & Com atividade remunerada & 1.679 & 53 \\
\hline & Dona de casa & 572 & 18 \\
\hline & Aposentado & 368 & 12 \\
\hline & Só estuda & 301 & 09 \\
\hline & Desempregado & 223 & 07 \\
\hline & Outras atividades & 49 & 02 \\
\hline \multirow{8}{*}{$\begin{array}{l}\text { Distribuição dos } \\
\text { que trabalham } \\
n=1.654\end{array}$} & Assalariado com carteira assinada & 644 & 39 \\
\hline & $\begin{array}{c}\text { Conta própria/temporário (bico, free } \\
\text { lancer) }\end{array}$ & 336 & 20 \\
\hline & Funcionário público & 229 & 14 \\
\hline & Assalariado sem carteira assinada & 208 & 13 \\
\hline & Conta própria regular (paga INSS) & 103 & 06 \\
\hline & Outras situações & 64 & 04 \\
\hline & Autônomo universitário/profissional liberal & 43 & 03 \\
\hline & Empregador (com mais de 2 empregados) & 27 & 02 \\
\hline
\end{tabular}

Fonte: Microdados da Pesquisa "Mulheres brasileiras e gênero nos espaços público e privado" (Fundação Perseu Abramo e Sesc, 2010). Compilação própria.

Nota: O total de unidades de análise no banco acessado (3.194) é inferior ao total de respondentes informado no relatório da pesquisa (3.546). A diferença, a menor, de 352 casos na base de dados provavelmente seja explicada por ajustes feitos pela equipe de execução. Para a elaboração da tabela do total de unidades de análise foram excluídos os casos de não se aplica, não respondeu ou não sabe, fazendo com que os valores de $n$ variem em cada um dos atributos.

No tocante às horas semanais gastas em atividades no lar ou na família (limpar, cozinhar, lavar e passar roupa e outros cuidados da casa), a maioria dos respondentes ( $71 \%$ ) afirmou envolver-se até cinco horas semanais; nos cuidados com os filhos, $57 \%$ despenderam até 10 horas semanais, enquanto $42 \%$ disseram ocupar de 10 a mais de 50 horas semanais. Quanto à carga horária semanal em trabalhos pagos, para $51 \%$ ela era de até 40 horas e para $43 \%$, de mais de 40 horas. Examinando-se mais detalhadamente esses percentuais gerais, foram identificadas diferenças quanto à intensidade do envolvimento feminino e masculino: a) nas atividades domésticas, enquanto $93 \%$ das mulheres afirmaram ocupar até cinco horas semanais, $54 \%$ dos homens preencheram o mesmo intervalo, ao passo que $46 \%$ deles não responderam a essa questão; b) no cuidado com os filhos, as mulheres tenderam a se envolver mais de 10 horas semanais (57\%, contra $22 \%$ dos homens, os quais se concentraram no intervalo de até 10 horas, em $76 \%$ ); c) nos trabalhos pagos, observou-se uma inversão: enquanto $58 \%$ dos homens tinham carga horária semanal de mais de 40 horas (contra 34\% delas), 59\% das mulheres trabalhavam até 40 horas semanais (contra 39\% deles). 
Tabela 2

Usos do tempo: horas semanais gastas em atividades do lar, cuidados com os filhos e nos trabalhos pagos

\begin{tabular}{|c|c|c|c|c|c|}
\hline \multicolumn{2}{|c|}{ Distribuição das horas semanais gastas em: } & \multirow{2}{*}{$\begin{array}{c}\begin{array}{c}\mathbf{N}^{\circ} \\
\text { absolutos }\end{array} \\
1.217\end{array}$} & \multirow{2}{*}{$\begin{array}{c}\begin{array}{c}\text { Geral } \\
\%\end{array} \\
71 \\
\end{array}$} & \multirow{2}{*}{$\begin{array}{c}\begin{array}{c}\text { Mulheres } \\
\%\end{array} \\
93 \\
\end{array}$} & \multirow{2}{*}{$\begin{array}{c}\begin{array}{c}\text { Homens } \\
\%\end{array} \\
54\end{array}$} \\
\hline $\begin{array}{l}\text { Atividades do lar (limpar, } \\
\text { cozinhar, lavar e passar }\end{array}$ & Até cinco horas & & & & \\
\hline $\begin{array}{l}\text { da casa) } \\
\mathrm{n}=1.725\end{array}$ & Não respondeu & 508 & 29 & 07 & 46 \\
\hline \multirow{6}{*}{$\begin{array}{l}\text { Cuidados com os filhos } \\
\text { (dar banho, alimentar, } \\
\text { levar à escola, ao médico } \\
\text { ou supervisionar) } \\
\mathrm{n}=1.217\end{array}$} & Até cinco horas & 429 & 35 & 24 & 50 \\
\hline & Mais de cinco a 10 horas & 263 & 22 & 19 & 26 \\
\hline & Mais de 10 a 30 horas & 381 & 31 & 40 & 20 \\
\hline & Mais de 30 a 50 horas & 94 & 08 & 12 & 02 \\
\hline & Mais de 50 horas & 35 & 03 & 05 & 00 \\
\hline & Não respondeu & 15 & 01 & 00 & 02 \\
\hline \multirow{7}{*}{$\begin{array}{l}\text { Trabalhos pagos } \\
\mathrm{n}=1.680\end{array}$} & Até 20 horas & 204 & 12 & 16 & 06 \\
\hline & De 20 a 30 horas & 180 & 11 & 13 & 08 \\
\hline & De 30 a 40 horas & 465 & 28 & 30 & 25 \\
\hline & De 40 a 50 horas & 506 & 30 & 23 & 41 \\
\hline & Mais de 50 horas & 224 & 13 & 11 & 17 \\
\hline & Nenhuma hora & 37 & 02 & 03 & 01 \\
\hline & $\begin{array}{l}\text { Não lembrou ou não } \\
\text { respondeu }\end{array}$ & 64 & 04 & 05 & 02 \\
\hline
\end{tabular}

Fonte: Microdados da Pesquisa "Mulheres brasileiras e gênero nos espaços público e privado" (Fundação Perseu Abramo e Sesc, 2010). Compilação própria.

Nota: Os valores de $n$ variam em cada item. Nesta tabela mantiveram-se os casos de não respondeu ou não lembrou devido às diferenças entre as respostas femininas e masculinas.

As categorias de resposta das questões da PNMB escolhidas para a análise das representações sociais abrangeram: a) nível de satisfação (totalmente satisfeito, satisfeito em parte, mais ou menos satisfeito, insatisfeito em parte, totalmente insatisfeito); b) nível de concordância (concordância total, concordância parcial, posição intermediária, discordância parcial, discordância total); c) afirmação ou negação (sim, não, em parte). Todas as questões do questionário da PNMB também incluíam as seguintes possibilidades de resposta, que não foram utilizadas em nossa análise: não sabe, não respondeu ou recusa. Para a análise das diferenças das respostas conforme o sexo (feminino ou masculino), foram realçadas as categorias antípodas e extremas (como proxys do conceito de violência simbólica) e agrupadas as respostas intermediárias em um único item (por meio da soma das categorias "concordância parcial" e "discordância parcial", e "parcialmente satisfatório" e "parcialmente insatisfatório"). Posteriormente, as variáveis (categorias de resposta) de interesse foram distribuídas de acordo com a sua pertinência ao espaço público ou ao privado. 
A análise comparativa das representações sociais de mulheres e homens foi operacionalizada por meio de distribuições de frequência e do cruzamento entre as variáveis selecionadas e o sexo dos respondentes (procedimento descriptive statistics/crosstab no SPSS $($ ) ). Utilizo como medida de associação entre as variáveis o teste qui-quadrado (Pearson Chi-Square), considerando como significativos os valores de significância iguais ou inferiores a 0,05. Posteriormente, nas tabelas de contingência, examino a distribuição de frequência dos valores esperados versus a dos valores observados das categorias de resposta cruzadas com "sexo", destacando os resíduos ajustados (adjusted residuals) com valor igual ou superior a dois.

As categorias de resposta selecionadas aparecem no Quadro 1. Duas delas apresentam percentuais abaixo de $10 \%$, todavia, apesar de sua baixa frequência, foram incluídas neste estudo porque têm a ver com opiniões arraigadas sobre a falta de capacidade de representação política das mulheres e sobre a obrigação de a mulher casada satisfazer sexualmente o marido. Em Apêndice constam todas as questões da PNMB selecionadas e cruzadas com a variável "sexo", com os respectivos números de casos, testes de qui-quadrado, categorias de resposta e distribuições de frequência. 


\section{Quadro 1 \\ Categorias de resposta cruzadas com a variável sexo}

\begin{tabular}{|c|c|c|c|}
\hline & Categorias de resposta (variáveis) & $\begin{array}{l}\text { \% } \\
\text { respostas }\end{array}$ & $\begin{array}{l}\text { Mulheres } \\
\text { x homens }\end{array}$ \\
\hline \multirow{9}{*}{ 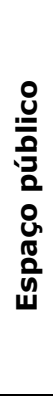 } & Dificilmente ou nunca - Votaria em um candidato que é a favor da legalização do aborto. & 74 & Igual \\
\hline & Dificilmente ou nunca - Votaria em um candidato que é a favor da união civil homoafetiva. & 46 & $\mathrm{H}$ \\
\hline & Dificilmente ou nunca - Votaria em um candidato homossexual. & 34 & $\mathrm{H}$ \\
\hline & A política é uma coisa NADA importante. & 17 & Igual \\
\hline & $\begin{array}{l}\text { Discordância total - A política seria melhor se houvesse mais mulheres em postos } \\
\text { importantes. }\end{array}$ & 12 & $\mathrm{H}$ \\
\hline & As mulheres NÃO estão preparadas para governar o país. & 14 & Igual \\
\hline & As mulheres NÃO estão preparadas para ser governadoras de estados. & 11 & $\mathrm{H}$ \\
\hline & As mulheres NÃO estão preparadas para governar cidades. & 10 & Igual \\
\hline & Dificilmente ou nunca - Votaria em candidata mulher. & 06 & Igual \\
\hline \multirow{10}{*}{ 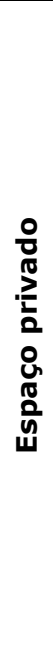 } & $\begin{array}{l}\text { Quanto à educação dos filhos pensa que (soma das categorias): (a) dar uns tapas de vez } \\
\text { em quando é necessário, ou (b) tem criança que só toma jeito apanhando bastante. }\end{array}$ & 74 & M \\
\hline & $\begin{array}{l}\text { No seu caso, quanto aos seus filhos, você (soma das categorias): a) de vez em quando dá } \\
\text { ou dava uns tapas; b) de vez em quando, dá ou dava uma surra; c) dava ou dá surras com } \\
\text { frequência. }\end{array}$ & 78 & M \\
\hline & $\begin{array}{l}\text { Concordância total - Com filhos pequenos é melhor que o homem trabalhe fora e a mulher } \\
\text { fique em casa. }\end{array}$ & 51 & Igual \\
\hline & $\begin{array}{l}\text { Discordância total - A mulher deveria ter o direito de decidir por interromper a gravidez, em } \\
\text { todas as situações. }\end{array}$ & 45 & $\mathrm{H}$ \\
\hline & $\begin{array}{l}\text { Concordância total - A mulher é quem deve decidir como será o trabalho doméstico, não } \\
\text { importa quem faça. }\end{array}$ & 42 & M \\
\hline & Concordância total - É principalmente o homem que deve sustentar a família. & 33 & $\mathrm{H}$ \\
\hline & Concordância total - Os homens, mesmo que queiram, não sabem fazer o trabalho da casa. & 22 & M \\
\hline & $\begin{array}{l}\text { Concordância total - Nas decisões importantes, é justo que na casa o homem tenha a última } \\
\text { palavra. }\end{array}$ & 15 & $\mathrm{H}$ \\
\hline & $\begin{array}{l}\text { Concordância total - Para o casal, é importante que o homem tenha mais experiência sexual } \\
\text { do que a mulher. }\end{array}$ & 14 & Igual \\
\hline & $\begin{array}{l}\text { Concordância total - A mulher casada deve satisfazer o marido sexualmente mesmo quando } \\
\text { não tem vontade. }\end{array}$ & 08 & Igual \\
\hline
\end{tabular}

Fonte: Microdados da pesquisa "Mulheres brasileiras e gênero nos espaços público e privado" (Fundação Perseu Abramo e Sesc, 2010). Compilação própria. Nota: Igual (sem diferença estatisticamente significativa entre homens e mulheres); H (mais homens pensam assim); M (mais mulheres pensam assim).

A seguir, são apresentados os principais resultados do estudo.

\section{Análise das representações de mulheres e homens}

Os resultados relativos às categorias de resposta selecionadas foram organizados conforme a abrangência do assunto (espaço público ou privado) nos gráficos a seguir.

\section{Espaço público}

O Gráfico 1 apresenta as categorias de resposta sobre assuntos relativos ao espaço público que não apresentaram diferença estatisticamente significativa entre mulheres e homens (tendo em vista os cruzamentos com a variável sexo). Destaca-se a alta frequência 
(74\%) de respondentes que dificilmente ou nunca votariam em um candidato que fosse a favor da legalização do aborto, enquanto $17 \%$ concordavam que a política não era algo importante. Além dessas assertivas, não houve diferenças entre mulheres e homens quanto à opinião de que as mulheres não estariam preparadas para serem presidentes ou prefeitas (totais gerais de $14 \%$ e $10 \%$, respetivamente) e quanto à afirmação de que dificilmente ou nunca votariam em mulher (6\%, no geral). Embora minoritários, o ponto a destacar nesses posicionamentos é a proximidade dos percentuais das respostas femininas e masculinas.

\section{Gráfico 1}

Espaço público - Categorias de resposta sem diferença estatisticamente significativa* entre mulheres e homens $(\%)$

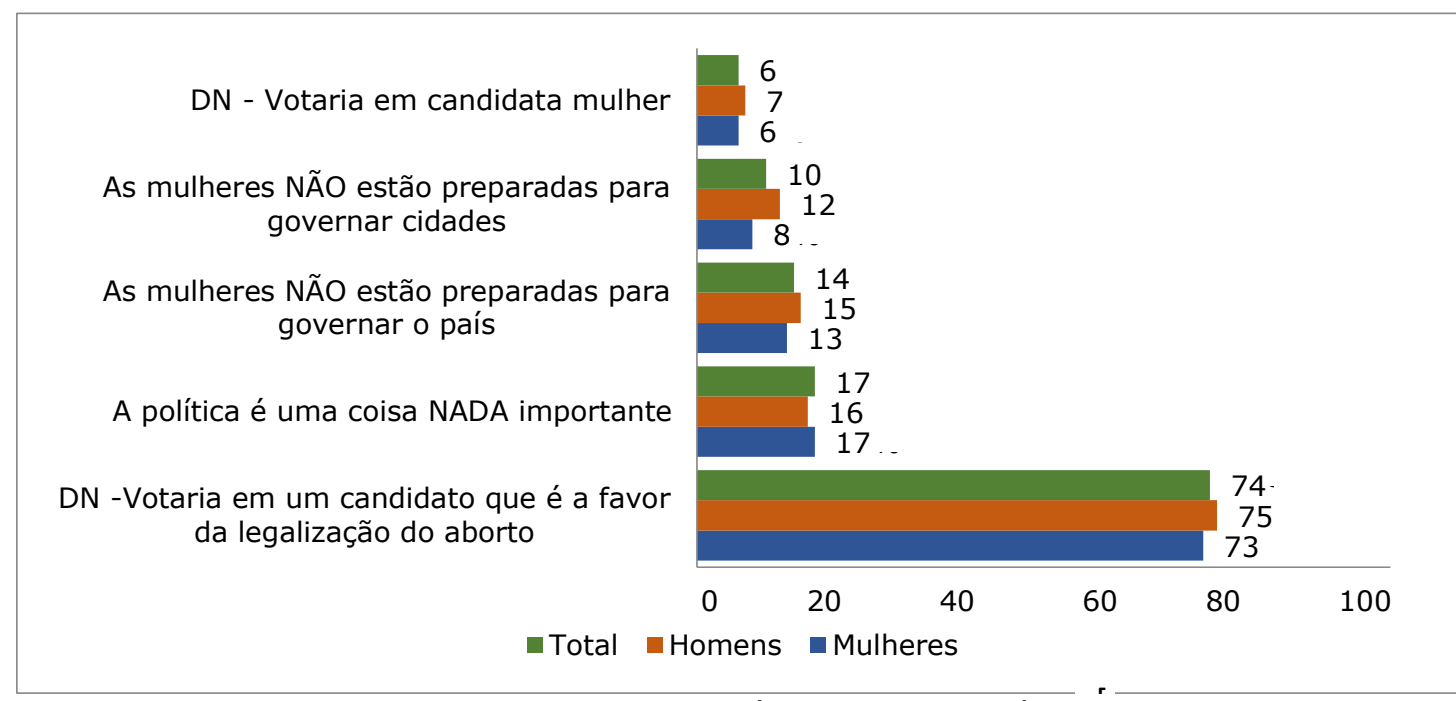

Fonte: Microdados da pesquisa "Mulheres brasileiras e gênero nos espaços público e privado" (Fundação Perseu Abramo e Sesc, 2010). Compilação própria.

Nota: $\mathrm{DN}=$ Dificilmente ou nunca.

* O nível de significância adotado é menor ou igual a 0,05 (Pearson Chi-Square).

Entre as categorias de resposta das questões sobre o espaço público que apresentaram diferença estatisticamente significativa entre mulheres e homens, não se encontrou qualquer predominância feminina. Em contrapartida, em quatro assertivas houve maior frequência relativa masculina, conforme se percebe no Gráfico 2. Com maior destaque aparecem as opiniões de que dificilmente ou nunca votariam em candidato homossexual ou candidato que fosse favorável à união homoafetiva, respectivamente, 34\% e $46 \%$ do conjunto de respondentes, sendo que na última as respostas masculinas ultrapassaram a metade do grupo (52\%). Menos frequentes (entre $11 \%$ e $12 \%$, no geral), as outras duas categorias de respostas referem-se à discordância total quanto à ideia de que a política melhoraria se as mulheres ocupassem postos importantes e à afirmação de 
que elas não estariam preparadas para governar estados. O interessante a destacar em ambos os enunciados é a predominância das respostas masculinas.

\section{Gráfico 2 \\ Espaço público - Categorias de resposta com maior frequência relativa entre os homens* (\%)}

As mulheres NÃO estão preparadas para ser governadoras de estados

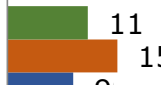

15

9

DT- A política seria melhor se houvesse mais mulheres em postos importantes

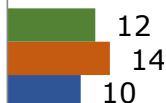

DN - Votaria em um candidato homossexual

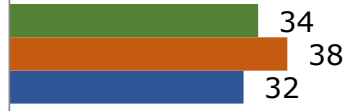

DN- Votaria em um candidato que é a favor da união civil homoafetiva

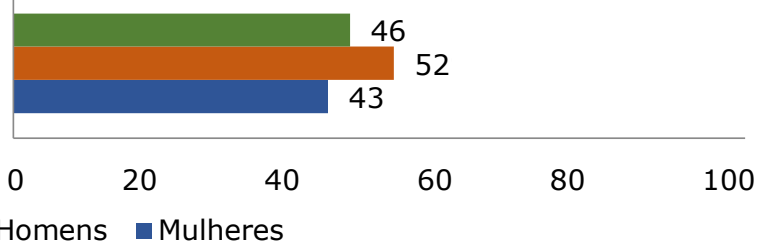

- Total Homens $\square$ Mulheres

Fonte: Microdados da pesquisa "Mulheres brasileiras e gênero nos espaços público e privado" (Fundação Perseu Abramo e Sesc, 2010). Compilação própria.

Nota: DN = soma das respostas dificilmente ou nunca; DT = Discordância total.

* Variáveis que apresentaram diferença estatisticamente significativa entre homens e mulheres. O nível de significância adotado é menor ou igual a 0,05 (Pearson Chi-Square).

\section{Espaço privado}

Com relação às representações atinentes ao espaço privado, nas categorias de resposta sem diferença significativa entre mulheres e homens, conforme o Gráfico 3, constata-se que $51 \%$ dos respondentes concordaram totalmente com a frase "Com filhos pequenos, é melhor que o homem trabalhe fora e a mulher fique em casa". É também digna de nota a parcela expressiva (14\%) de concordância total com a afirmação "Para o casal, é importante que o homem possua maior experiência sexual". Por último, embora com frequência ínfima ( $8 \%$, no geral), nota-se não haver diferença entre homens e mulheres na concordância total com a frase de que a mulher casada deve satisfazer sexualmente o marido, mesmo sem ter vontade. 


\section{Gráfico 3 \\ Espaço privado - Categorias de resposta sem diferença estatisticamente significativa* entre mulheres e homens (\%)}

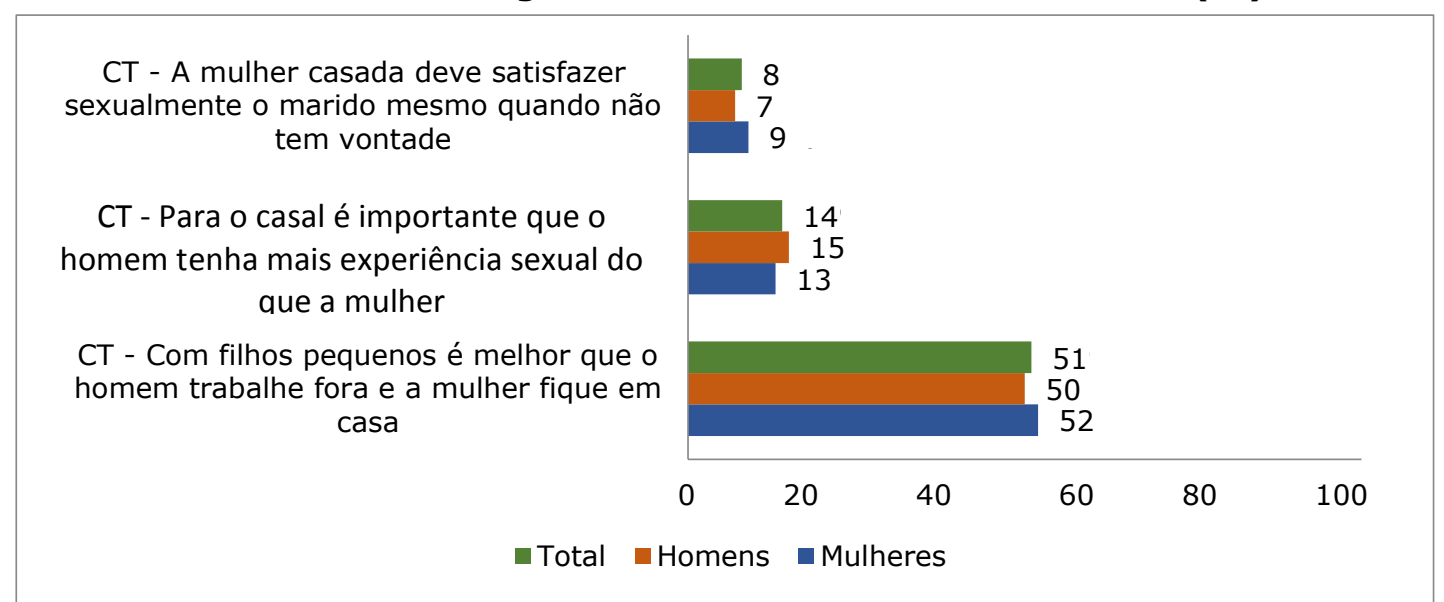

Fonte: Microdados da pesquisa "Mulheres brasileiras e gênero nos espaços público e privado" (Fundação Perseu Abramo e Sesc, 2010). Compilação própria.

Nota: $\mathrm{CT}=$ Concordância total.

* O nível de significância adotado é menor ou igual a 0,05 (Pearson Chi-Square).

O Gráfico 4 apresenta as categorias de resposta relacionadas com o espaço privado com maior frequência masculina. Quanto à assertiva de que a mulher deveria ter o direito de interromper a gravidez, enquanto, no geral, $45 \%$ dos respondentes discordaram, entre os homens essa opção de resposta chegou a $49 \%$ contra $43 \%$ de discordância entre as mulheres (a diferença, embora significativa em termos estatísticos, não é expressiva). Seguem as opiniões relativas ao papel masculino de provedor: concordância total de que é principalmente o homem que deve sustentar a família (33\% no geral, $37 \%$ entre os homens) e de que a última palavra nas decisões importantes deve ser a do homem (15\% no geral, $21 \%$ entre os homens). 


\section{Gráfico 4 \\ Espaço privado - Categorias de resposta com maior frequência relativa entre os homens* (\%)}

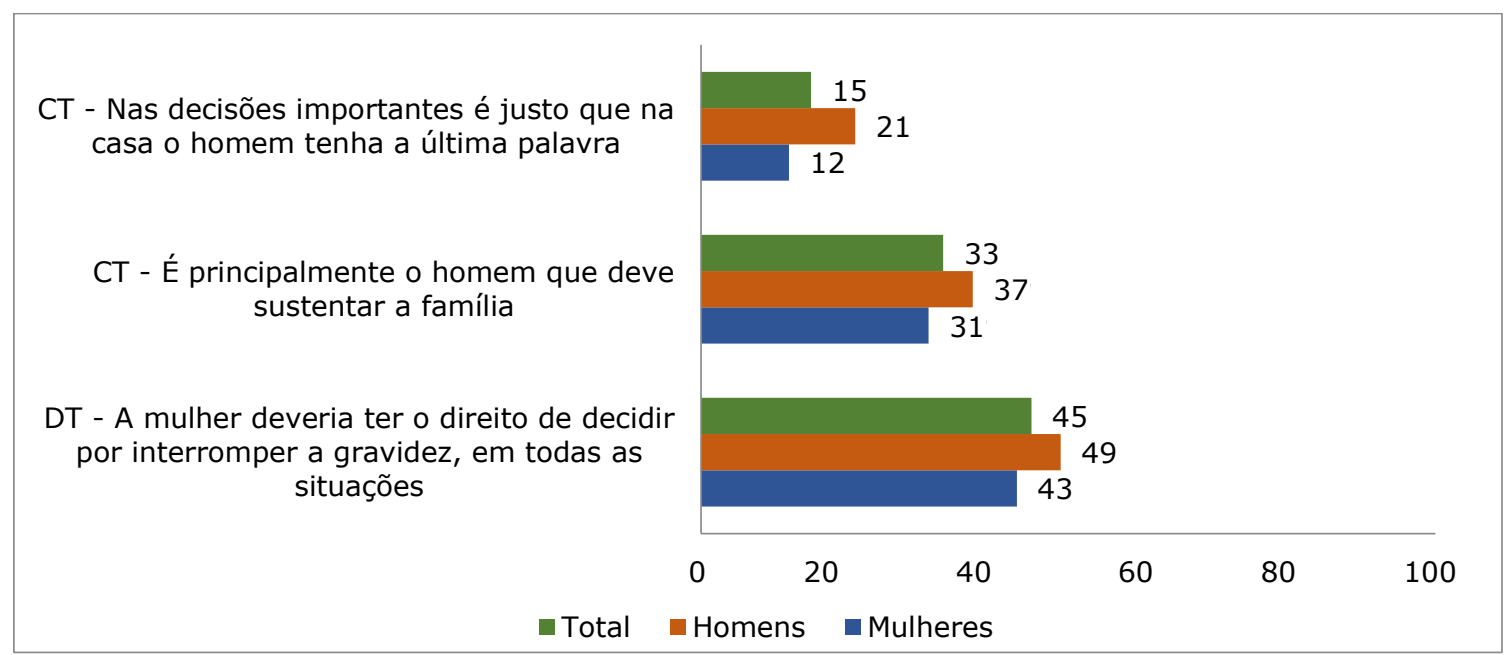

Fonte: Microdados da pesquisa "Mulheres brasileiras e gênero nos espaços público e privado" (Fundação Perseu Abramo e Sesc, 2010). Compilação própria.

Nota: $\mathrm{CT}=$ Concordância total; DT = Discordância total.

* Variáveis que apresentaram diferença estatisticamente significativa entre homens e mulheres. O nível de significância adotado é menor ou igual a 0,05 (Pearson Chi-Square).

No tocante aos assuntos de âmbito privado cujas respostas tiveram maior frequência relativa entre as mulheres, destacam-se, no Gráfico 5, a opinião sobre a necessidade de agressão física para a educação dos filhos e o reconhecimento do uso efetivo dessa prática (total de $74 \%$ e $78 \%$, respectivamente).

Em ambos os casos, a prevalência das respostas femininas (79\% e $85 \%$ ) sugere que as mulheres são, com maior frequência em relação aos homens, as principais autoras dos maus-tratos contra crianças. Esse fato evoca duas situações: a) as mulheres são as principais responsáveis pelo cuidado dos filhos, convivendo mais horas com eles, como já apontado; b) elas vivenciam a "síndrome do pequeno poder" (Saffioti, 1989, p. 18), poder que é exercido, principalmente, sobre as crianças de sua própria família: filhos, sobrinhos, netos. Esses seriam os sujeitos mais dominados na hierarquia familiar:

A mulher, ou por síndrome do pequeno poder ou por delegação do macho, acaba exercendo, não raro, a tirania contra crianças, último elo da cadeia de assimetrias. Assim, o gênero, a família e o território domiciliar contêm hierarquias, nas quais os homens figuram como dominadores-exploradores e as crianças como os elementos mais dominados-explorados (Saffioti, 1999, p. 84).

Ademais, quanto à divisão sexual do trabalho doméstico, merecem destaque as opiniões de que a decisão sobre como desenvolvê-lo cabe à mulher e de que os homens 
LETÍCIA MARIA SCHABBACH

não sabem executá-lo ( $42 \%$ e $22 \%$ dos respondentes, com menor frequência masculina). Para as entrevistadas, os percentuais nesses quesitos foram de $45 \%$ e $24 \%$, respectivamente.

\section{Gráfico 5}

\section{Espaço privado - Categorias de resposta com maior frequência relativa entre as mulheres* $(\%)$}

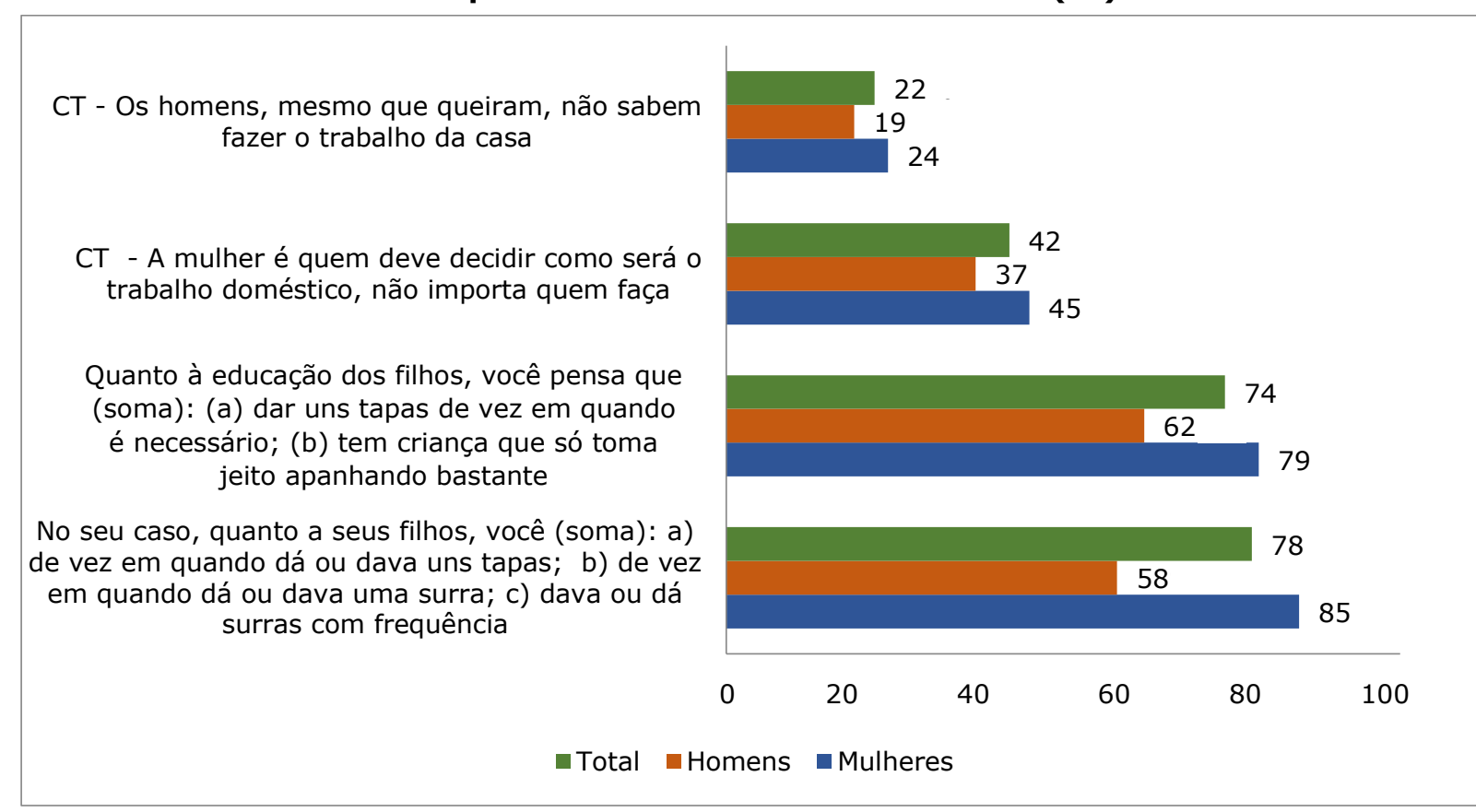

Fonte: Microdados da pesquisa "Mulheres brasileiras e gênero nos espaços público e privado" (Fundação Perseu Abramo e Sesc, 2010). Compilação própria.

Nota: $\mathrm{CT}=$ Concordância total.

* Variáveis que apresentaram diferença estatisticamente significativa entre homens e mulheres. O nível de significância adotado é menor ou igual a 0,05 (Pearson Chi-Square).

\section{Conclusão}

O objetivo deste artigo foi examinar, por um lado, a confluência de representações sociais sobre assuntos atinentes aos espaços público e privado e, por outro, comparar opiniões femininas e masculinas a esse respeito. A partir da seleção de questões existentes nos microdados da pesquisa nacional "Mulheres brasileiras e gênero nos espaços público e privado" (Fundação Perseu Abramo e Sesc, 2010), foram realizados procedimentos estatísticos no software SPSS ${ }^{\circledR}$, especialmente o cruzamento entre variáveis categóricas e o teste do qui-quadrado, a fim de verificar a existência (ou não) de associação estatisticamente significativa entre aquelas e o registro de sexo dos respondentes. 
A constituição de gênero é relacional, ou seja, mulheres e homens constroem-se de forma recíproca (Scott, 1986), assim também as suas representações coletivas (Durkheim, 1996) ou sociais (Moscovici, 2003). A fim de dar conta desse aspecto foram comparadas as opiniões femininas e masculinas sobre um conjunto de assertivas em torno da participação da mulher na política institucional e como governante, bem como sobre a titularidade pelo sustento da casa e pela organização do trabalho doméstico. Adicionalmente, foram incluídos os posicionamentos sobre, dentre outros tópicos, a possibilidade de voto em candidato homossexual, ou em alguém que apoie a legalização do aborto ou, ainda, que defenda a união civil homoafetiva.

As questões foram classificadas conforme a sua pertinência a um dos espaços: público ou privado. Embora tal divisão não seja consensual na literatura sobre gênero (Biroli, 2014), considero que as formas de inserção masculina e feminina em cada um dos espaços são diferentes (Fougeyrollas-Schwebel, 2009), além de serem produzidas identidades específicas e generificadas (Scott, 1986).

O conjunto dos dados da pesquisa mostra, por um lado, não haver distinções expressivas entre as opiniões de mulheres e homens sobre as questões concernentes ao espaço público e à participação da mulher na política institucional, pois, das nove assertivas apresentadas, em cinco delas não foram encontradas diferenças estatisticamente significativas entre os grupos. Ademais, mesmo quando foram encontradas diferenças estatisticamente significativa entre as opiniões de homens e mulheres, elas foram diminutas em termos percentuais. Assim, tanto elas quanto eles não acreditam na capacidade de a mulher governar o país (14\%) ou municípios (10\%) e dificilmente ou nunca votariam em mulher (6\%). Ainda que tais opiniões tenham sido pouco frequentes, a convergência dos posicionamentos de mulheres e homens remete à "agorafobia socialmente imposta" (Bourdieu, 1999, p. 62) ou à falta de manejo feminino para com os "macropoderes" (Saffioti, 1999, p. 86). E isso em agosto de 2010, início da campanha eleitoral que levaria, em novembro seguinte, Dilma Rousseff à presidência da República (e cujo pleito colocou Marina Silva como a terceira colocada do primeiro turno).

Surpreendeu-me, também, a existência de forte rechaço à causa da legalização do aborto e de preconceito em relação aos direitos civis e políticos de lésbicas, gays, bissexuais, travestis, transexuais e transgêneros (LGBTTs), como ilustram as respostas negativas quanto à possibilidade de voto em candidato a favor da legalização do aborto (74\% das respostas, no geral), da união civil homoafetiva (46\%), ou em candidato(a) homossexual (34\%).

Por outro lado, dentre as evidências constatadas nas questões concernentes ao espaço privado, pareceu digna de nota a alta proporção de pessoas que concordam com o uso de agressões físicas, ainda que eventualmente, para a educação de crianças e/ou que as praticam (77\% e $74 \%$, respectivamente). A predominância feminina em ambas as questões pode estar associada ao maior encargo das mulheres com os cuidados dos filhos, ao mesmo tempo em que sugere a presença da "síndrome do pequeno poder" entre elas 
LETÍCIA MARIA SCHABBACH

(Saffioti, 1989, 1999). Em adendo, foi verificado que: metade dos entrevistados (51\%, no geral) concorda com a assertiva de que, na presença de filhos pequenos, a mulher deve permanecer em casa enquanto o homem trabalha fora; $45 \%$ discordam totalmente de que a mulher deva ter o direito de interromper a gravidez; $42 \%$ entendem que as mulheres é que devem decidir sobre como realizar o trabalho doméstico; e 33\% consideram que o sustento da família deve ser responsabilidade masculina. Em comparação com o primeiro grupo de assertivas (espaço público), nesse conjunto houve maior discrepância entre as opiniões femininas e masculinas, precisamente em sete de um total de 10 questões. A maior frequência das respostas femininas em duas delas - concordância total com as afirmações de que a decisão sobre os afazeres domésticos deve ser da mulher e de que os homens não sabem fazer o trabalho de casa, mesmo que queiram - denota que uma parcela das entrevistadas ( $45 \%$ e $24 \%$, respectivamente) não vislumbra uma divisão mais equitativa dos encargos domésticos.

Tais achados conduzem à conclusão de que, embora a maioria dos entrevistados tenha reconhecido uma melhora da situação das mulheres (nas perguntas iniciais da pesquisa), muitas de suas representações sociais/opiniões - enquanto manifestações difusas de violência simbólica veiculadas na comunicação intersubjetiva - legitimam e reproduzem as assimetrias que alicerçam a organização social de gênero (Scott, 1986). Ao mesmo tempo, elas reforçam a arraigada dicotomia entre o espaço público - do trabalho dito produtivo e da macropolítica, com participação hegemonicamente masculina - e o espaço privado - das relações íntimas e do trabalho reprodutivo e feminino (Safiotti, 1999; Bandeira e Preturlan, 2016; Barajas, 2016).

\section{Referências bibliográficas}

Bandeira, L. M.; Preturlan, R. B. "As pesquisas sobre uso do tempo e a promoção da igualdade de gênero no Brasil". In: FonTOURA, N.; ARAújo, C. (orgs.). Uso do tempo e gênero. Brasília: Secretaria Especial de Política para Mulheres; Instituto de Pesquisa Econômica Aplicada. Rio de Janeiro: Universidade do Estado do Rio de Janeiro, p. 43-59, 2016.

BARAJAS, M. L. P. L. Avanços na América Latina na medição e valoração do trabalho não remunerado realizado pelas mulheres. In: FonTOURA, N.; ARAújo, C. (orgs.). Uso do tempo e gênero. Brasília: Secretaria Especial de Política para Mulheres; Instituto de Pesquisa Econômica Aplicada. Rio de Janeiro: Universidade do Estado do Rio de Janeiro, p. 21-42, 2016.

BAUER, M. A popularização da ciência como imunização cultural: a função de resistência das representações sociais. In: GUARESCHI, P.; JOVCHELOVITCH, S. (orgs.). Textos em representações sociais. Petrópolis: Vozes, p. 223-257, 1994.

BAuer, M.; GASKelL, G. (eds.). Pesquisa qualitativa com texto, imagem e som: um manual prático. Petrópolis: Vozes, 2008.

Biroli, F. O público e o privado. In: Miguel, L. F.; Biroli, F. Feminismo e política: uma introdução. São Paulo: Boitempo, 2014.

BouRdieu. P. O poder simbólico. Lisboa: Difel, 1989. 
. A economia das trocas simbólicas. São Paulo: Perspectiva, 1992.

A dominação masculina. Rio de Janeiro: Bertrand Brasil, 1999.

BRASIL. Lei Federal no 9.504, de 30 de setembro de 1997. Estabelece normas para eleições. Brasília: Presidência da República, 1997.

. Lei Federal no 11.340 , de 7 de agosto de 2006. Cria mecanismos para coibir a violência

doméstica e familiar contra a mulher; dispõe sobre a criação dos Juizados de Violência Doméstica e Familiar contra a Mulher; altera o Código de Processo Penal, o Código Penal e a Lei de Execução Penal; e dá outras providências. Brasília: Presidência da República, 2006.

Brasil. Tribunal Superior Eleitoral. Resultados das eleições 2016. Brasília, 2016. Disponível em: <http://www.tse.jus.br/>. Acesso em: 13 mar. 2019.

Tribunal Superior Eleitoral. Resultados das eleições 2018. Brasília, 2018. Disponível em: <http://www.tse.jus.br/>. Acesso em: 13 mar. 2019.

CASTRO, M. G. Temas persistentes e enfoques emergentes resgatando o conceito de patriarcado em gênero. In: ARILHA, M., et al. (orgs.). Diálogos transversais em gênero e fecundidade: articulações contemporâneas. Campinas: Librum Editora, Associação Brasileira de Estudos Populacionais (Abep), 2012. Disponível em: <http://www.abep.org.br/publicacoes/index.php/livros>. Acesso em: 19 jan. 2019.

Charaudeau, P. Discurso das mídias. 2a ed. São Paulo: Contexto, 2013.

Conceição, A. C. L. "Teorias feministas: da questão da mulher ao enfoque de gênero". Revista Brasileira de Sociologia da Emoção, João Pessoa, vol. 8, no 24, p. 738-757, dez. 2009.

DEDECCA, C. S. Uso do tempo e gênero: uma dimensão da desigualdade socioeconômica brasileira. In: ARILHA, M., et al. (orgs.). Diálogos transversais em gênero e fecundidade: articulações contemporâneas. Campinas: Librum Editora, Associação Brasileira de Estudos Populacionais (Abep), 2012. Disponível em: <http://www.abep.org.br/publicacoes/index.php/livros>. Acesso em: 20 jan. 2019.

DuRkheim, E. As regras do método sociológico. São Paulo: Companhia Editora Nacional, 1974. . As formas elementares da vida religiosa. São Paulo: Martins Fontes, 1996.

Fontoura, N.; Araújo, C. Introdução. In: Fontoura, N.; ARaújo, C. (orgs.). Uso do tempo e gênero. Brasília: Secretaria Especial de Política para Mulheres; Instituto de Pesquisa Econômica Aplicada. Rio de Janeiro: Universidade do Estado do Rio de Janeiro, p. 17-20, 2016.

FOUCAULT, M. Dits et ecrits. Paris: Galimard, 1984.

. Arqueologia do saber. Rio de Janeiro: Forense Universitária, 1987.

. História da sexualidade I: A vontade de saber. Rio de Janeiro: Graal, 1988.

Fougeyrollas-Schwebel, D. Trabalho doméstico. In: HiRATA, H., et al. (orgs.). Dicionário crítico do feminismo. São Paulo: Editora Unesp, p. 257-262, 2009.

Fundação Perseu Abramo; Sesc - Serviço Social do Comércio. Pesquisa "Mulheres brasileiras e gênero nos espaços público e privado". São Paulo: 2010. Disponível em:

<http://fpadados.fpabramo.org.br/>. Acesso em: 10 de fevereiro de 2018.

Hirata, H., et al. (orgs.). Dicionário crítico do feminismo. São Paulo: Editora Unesp, 2009. 
LETÍCIA MARIA SCHABBACH

ibge - instituto Brasileiro de Geografia e Estatística. Pesquisa Nacional por Amostra de Domicílios Contínua. Suplemento Outras Formas de Trabalho. Brasília, 2019a.

. Pesquisa Nacional por Amostra de Domicílios (PNAD) Contínua Trimestral. Tabelas 4093 e 5429. Brasília, 10 trimestre de 2019b.

JODELET, D. La representación social: fenómenos, concepto y teoria. In: Moscovici, S. (org.). Psicologia social. Barcelona: Paidós, 1985.

. Représentations sociales: un domaine en expansion. In: JODELET, D. (org.). Les représentations sociales. Paris: PUF, 1989.

JOVCHELOVITCH, S. Vivendo a vida com os outros: intersubjetividade, espaço público e representações sociais. In: GUARESCHI, P.; JovCHELOVITCH, S. (orgs.). Textos em representações sociais. Petrópolis: Vozes, 1994.

. Os contextos do saber: representações, comunidade e cultura. Petrópolis: Vozes, 2011.

LeVIN, J.; Fox, J. A. Estatística para ciências humanas. São Paulo: Prentice Hall, 2004.

MARX, K. Prefácio. In: MARX, K. Contribuição à crítica da economia política. São Paulo: Expressão Popular, [1859] 2008.

Miguel, L. F. "Perspectivas sociais e dominação simbólica: a presença política das mulheres entre Iris Marion Young e Pierre Bourdieu". Revista Sociologia e Política, Curitiba, vol. 18, no 6, p. 25-49, jun. 2010.

Minayo, M. C. S. (org.). Pesquisa social: teoria, método e criatividade. Petrópolis: Vozes, 1994.

Moscovici, S. Representações sociais: investigações em psicologia social. Petrópolis: Vozes, 2003.

MotTA, D. A. "Ditadura, direitos humanos e dilemas da Justiça de Transição: representações sociais e discursos sobre a Comissão Nacional da Verdade nas revistas semanais de informação geral". Tese de Doutorado em Sociologia, Programa de Pós-Graduação em Sociologia, Universidade Federal do Rio Grande do Sul. Porto Alegre, 2018.

PAteman, C. O contrato sexual. São Paulo: Paz e Terra, 1993.

Porto, M. S. G. "Crenças, valores e representações sociais da violência". Sociologias, Porto Alegre, no 16, p. 250-273, 2006.

PORTO, M. S. G. Sociologia da violência. Brasília: Verbana, 2010.

POSTER, M. Foucault, marxismo e história. Buenos Aires: Paidós, 1987.

SAfFioti, H. A síndrome do pequeno poder. In: AzeVedo, M. A.; Guerra, V. N. A. (orgs.). Crianças vitimizadas: a síndrome do pequeno poder. São Paulo: Iglu Editora, 1989.

. "Já se mete a colher em briga de marido e mulher". São Paulo em Perspectiva, São Paulo, vol. 13, no 4, p. 82-91, 1999.

. Gênero, patriarcado, violência. Fundação Perseu Abramo, São Paulo, 2004.

ScotT, J. W. "Gender: a useful category of historical analysis". American Historical Review, vol. 91, no 5, p. 1.053-1.075, dez. 1986.

SpINK, M. J. "O conceito de representação social na abordagem psicossocial". Cadernos de Saúde Pública, vol. 3, no 9, p. 300-308, jul.-set. 1993. 
VALA, J. Representações sociais e psicologia social do pensamento quotidiano. In: VALA, J.; MONTEIRO, M. B. (orgs.). Psicologia social. 4a ed. Lisboa: Fundação Calouste Gulbenkian, 2000.

VENTURI, G.; Godinho, T. (orgs.). Mulheres brasileiras e gênero nos espaços público e privado: uma década de mudanças na opinião pública. São Paulo: Fundação Perseu Abramo; Edições Sesc, 2013.

Weber, M. Economía y sociedad. México: Fondo de Cultura Económica, 1969.

WieVIORKA, M. Violence en France. Paris: Seuil, 1999.

WORLD BANK GROUP. "Data: proportion of seats held by women in national parliaments (\%)", 2018. Disponível em: <https://data.worldbank.org/indicator/SG.GEN.PARL.ZS?locations=ZJ\&view=chart>. Acesso em: 2 jun. 2019. 
Tabela 3

Variáveis/questões relativas ao espaço público

\begin{tabular}{|c|c|c|c|c|c|}
\hline Questões & $\begin{array}{c}\text { Asymp. } \\
\text { Sign./(N) }\end{array}$ & Categorias de resposta & $\begin{array}{c}\text { Distribuição } \\
\text { geral }(\%)\end{array}$ & $\begin{array}{l}\text { Mulheres } \\
(\%)\end{array}$ & $\begin{array}{l}\text { Homens } \\
(\%)\end{array}$ \\
\hline $\begin{array}{l}\text { Gostaria que você dissesse se: } \\
\text { poderia votar, dificilmente votaria, } \\
\text { nunca votaria em um candidato(a) } \\
\text { que é a favor da legalização do } \\
\text { aborto. }\end{array}$ & $\begin{array}{l}0,210 \\
(1.217)\end{array}$ & $\begin{array}{l}\text { - Poderia votar } \\
\text { - Dificilmente votaria } \\
\text { - Nunca votaria } \\
\text { - Não sabe/não respondeu }\end{array}$ & $\begin{array}{l}22,6 \\
17,8 \\
56,0 \\
03,5\end{array}$ & $\begin{array}{l}23,1 \\
16,4 \\
56,9 \\
03,6\end{array}$ & $\begin{array}{l}21,8 \\
20,0 \\
54,7 \\
03,5\end{array}$ \\
\hline $\begin{array}{l}\text { Gostaria que você dissesse se: } \\
\text { poderia votar, dificilmente votaria, } \\
\text { nunca votaria em um candidato(a) } \\
\text { que é favor da união civil de pessoas } \\
\text { do mesmo sexo. }\end{array}$ & $\begin{array}{c}0,004 \\
(1.217)\end{array}$ & $\begin{array}{l}\text { - Poderia votar } \\
\text { - Dificilmente votaria } \\
\text { - Nunca votaria } \\
\text { - Não sabe/não respondeu }\end{array}$ & $\begin{array}{l}49,5 \\
10,8 \\
35,5 \\
04,3\end{array}$ & $\begin{array}{l}52,4 \\
08,9 \\
33,7 \\
05,1\end{array}$ & $\begin{array}{l}45,1 \\
13,6 \\
38,3 \\
03,1\end{array}$ \\
\hline $\begin{array}{l}\text { Gostaria que você dissesse se: } \\
\text { poderia votar, dificilmente votaria, } \\
\text { nunca votaria em um candidato(a) } \\
\text { que é homossexual - gay ou lésbica. }\end{array}$ & $\begin{array}{c}0,044 \\
(1.217)\end{array}$ & $\begin{array}{l}\text { - Poderia votar } \\
\text { - Dificilmente votaria } \\
\text { - Nunca votaria } \\
\text { - Não sabe/não respondeu }\end{array}$ & $\begin{array}{l}62,4 \\
07,9 \\
26,5 \\
03,3\end{array}$ & $\begin{array}{l}63,9 \\
06,8 \\
25,2 \\
04,1\end{array}$ & $\begin{array}{l}60,1 \\
09,5 \\
28,4 \\
02,1\end{array}$ \\
\hline $\begin{array}{l}\text { Em sua opinião, a política é uma } \\
\text { coisa... }\end{array}$ & $\begin{array}{c}0,017 * \\
(3.194)\end{array}$ & $\begin{array}{l}\text { - Muito importante } \\
\text { - Mais ou menos importante } \\
\text { - Nada importante } \\
\text { - Não sabe ou não respondeu }\end{array}$ & $\begin{array}{l}54,1 \\
26,7 \\
16,9 \\
02,3\end{array}$ & $\begin{array}{l}52,4 \\
27,5 \\
17,4 \\
02,6\end{array}$ & $\begin{array}{l}57,8 \\
24,8 \\
15,9 \\
01,5\end{array}$ \\
\hline $\begin{array}{l}\text { Você concorda ou discorda da frase: } \\
\text { "A política seria melhor se tivesse } \\
\text { mais mulheres em postos } \\
\text { importantes"? }\end{array}$ & $\begin{array}{c}0,000 \\
(1.217)\end{array}$ & $\begin{array}{l}\text { - Concorda totalmente } \\
\text { - Concorda ou discorda em parte } \\
\text { - É indiferente (nem C e nem D) } \\
\text { - Discorda totalmente } \\
\text { - Não sabe ou não respondeu }\end{array}$ & $\begin{array}{l}36,1 \\
31,8 \\
17,7 \\
11,8 \\
02,7\end{array}$ & $\begin{array}{l}45,8 \\
21,9 \\
11,8 \\
10,0 \\
03,3\end{array}$ & $\begin{array}{l}21,4 \\
35,8 \\
26,5 \\
14,4 \\
01,9\end{array}$ \\
\hline $\begin{array}{l}\text { Em sua opinião, as mulheres estão } \\
\text { preparadas para serem presidente do } \\
\text { Brasil? }\end{array}$ & $\begin{array}{c}0,461 \\
(1.239)\end{array}$ & $\begin{array}{l}\text { - Sim } \\
\text { - Não } \\
\text { - Em termos, depende } \\
\text { - Não sabe }\end{array}$ & $\begin{array}{l}79,5 \\
14,0 \\
02,5 \\
04,0\end{array}$ & $\begin{array}{l}79,6 \\
13,2 \\
02,7 \\
04,5\end{array}$ & $\begin{array}{l}79,4 \\
15,3 \\
02,2 \\
03,2\end{array}$ \\
\hline $\begin{array}{l}\text { Em sua opinião, as mulheres estão } \\
\text { preparadas para serem governadoras } \\
\text { de estado? }\end{array}$ & $\begin{array}{c}0,014 \\
(1.239)\end{array}$ & $\begin{array}{l}\text { - Sim } \\
\text { - Não } \\
\text { - Em termos, depende } \\
\text { - Não sabe }\end{array}$ & $\begin{array}{l}83,6 \\
11,2 \\
02,2 \\
03,0\end{array}$ & $\begin{array}{l}85,2 \\
09,9 \\
02,3 \\
03,5\end{array}$ & $\begin{array}{l}81,3 \\
14,5 \\
02,0 \\
02,2\end{array}$ \\
\hline $\begin{array}{l}\text { Em sua opinião, as mulheres estão } \\
\text { preparadas para serem prefeitas e } \\
\text { governarem cidades? }\end{array}$ & $\begin{array}{c}0,086 \\
(1.239)\end{array}$ & $\begin{array}{l}\text { - Sim } \\
\text { - Não } \\
\text { - Em termos, depende } \\
\text { - Não sabe }\end{array}$ & $\begin{array}{l}85,8 \\
09,9 \\
01,9 \\
02,4\end{array}$ & $\begin{array}{l}86,5 \\
08,4 \\
02,2 \\
02,9\end{array}$ & $\begin{array}{l}84,7 \\
12,1 \\
01,4 \\
01,8\end{array}$ \\
\hline $\begin{array}{l}\text { Gostaria que você dissesse se: } \\
\text { poderia votar, dificilmente votaria, } \\
\text { nunca votaria em candidata mulher. }\end{array}$ & $\begin{array}{c}0,122 \\
(1.217)\end{array}$ & $\begin{array}{l}\text { - Poderia votar } \\
\text { - Dificilmente votaria } \\
\text { - Nunca votaria } \\
\text { - Não sabe/não respondeu }\end{array}$ & $\begin{array}{l}92,5 \\
02,4 \\
03,9 \\
01,2\end{array}$ & $\begin{array}{l}92,7 \\
02,6 \\
03,3 \\
01,4\end{array}$ & $\begin{array}{l}92,2 \\
02,1 \\
04,9 \\
00,3\end{array}$ \\
\hline
\end{tabular}

Fonte: Microdados da Pesquisa "Mulheres brasileiras e gênero nos espaços público e privado" (Fundação Perseu Abramo e Sesc, 2010). Compilação própria.

Notas: Asymp. Sign./(N) = Asymptotic Significance e número de respostas. Nos resultados destacados na cor cinza foram encontradas diferenças estatisticamente significativas entre as categorias de resposta de mulheres e de homens, considerando o teste do Quiquadrado (Sign. < ou =0,05) e o resíduo ajustado (Adjusted Residual $>$ ou $=2,0$ ). * Adjusted Residual $<2,0$. 
Tabela 4

Variáveis/questões relativas ao espaço privado

\begin{tabular}{|c|c|c|c|c|c|}
\hline Questões & $\begin{array}{c}\text { Asymp. } \\
\text { Sign./(N) }\end{array}$ & Categorias de resposta & $\begin{array}{c}\text { Distribuição } \\
\text { geral }(\%)\end{array}$ & $\begin{array}{l}\text { Mulheres } \\
(\%)\end{array}$ & $\begin{array}{c}\text { Homens } \\
(\%)\end{array}$ \\
\hline $\begin{array}{l}\text { Algumas pessoas acham que, para } \\
\text { educar bem os filhos, às vezes é preciso } \\
\text { dar uns tapas neles. Outras acham que } \\
\text { em nenhuma situação se deve bater nos } \\
\text { filhos. Qual das seguintes frases se } \\
\text { aproxima mais do que você pensa sobre } \\
\text { isso? }\end{array}$ & $\begin{array}{c}0,000 \\
(3.161)\end{array}$ & $\begin{array}{l}\text { - Bater em criança é errado em qualquer } \\
\text { situação } \\
\text { - Dar uns tapas de vez em quando é } \\
\text { necessário } \\
\text { - Tem criança que só toma jeito } \\
\text { apanhando bastante } \\
\text { - Outras respostas }\end{array}$ & $\begin{array}{l}26,0 \\
71,5 \\
02,1 \\
00,4\end{array}$ & $\begin{array}{l}21,0 \\
76,5 \\
02,2 \\
00,3\end{array}$ & $\begin{array}{l}37,1 \\
60,3 \\
01,8 \\
00,8\end{array}$ \\
\hline $\begin{array}{l}\text { E no seu caso... (respondida pelos(as) } \\
\text { que tinham filhos) }\end{array}$ & $\begin{array}{c}0,000 \\
(2.178)\end{array}$ & $\begin{array}{l}\text { - Nunca deu nenhum tapa em um filho } \\
\text { - De vez em quando dá ou dava uns } \\
\text { tapas } \\
\text { - De vez em quando dá ou dava uma } \\
\text { surra } \\
\text { - Dá ou dava surras com frequência }\end{array}$ & $\begin{array}{l}22,4 \\
71,0 \\
05,9 \\
00,7\end{array}$ & $\begin{array}{l}14,9 \\
77,5 \\
06,7 \\
00,3\end{array}$ & $\begin{array}{l}42,0 \\
54,1 \\
03,6 \\
00,8\end{array}$ \\
\hline $\begin{array}{l}\text { Você concorda ou discorda da frase: } \\
\text { "Quando têm filhos pequenos, é melhor } \\
\text { que o homem trabalhe fora e a mulher } \\
\text { fique em casa"? }\end{array}$ & $\begin{array}{c}0,084 \\
(1.239)\end{array}$ & $\begin{array}{l}\text { - Concorda totalmente } \\
\text { - Concorda ou discorda em parte } \\
\text { - É indiferente (nem C e nem D) } \\
\text { - Discorda totalmente } \\
\text { - Não sabe, não respondeu }\end{array}$ & $\begin{array}{l}51,0 \\
31,0 \\
06,9 \\
10,5 \\
00,6\end{array}$ & $\begin{array}{l}52,0 \\
29,5 \\
05,9 \\
11,8 \\
00,8\end{array}$ & $\begin{array}{l}49,6 \\
33,1 \\
08,3 \\
08,5 \\
00,4\end{array}$ \\
\hline $\begin{array}{l}\text { Você concorda ou discorda de que a } \\
\text { mulher deveria ter o direito de decidir se } \\
\text { continua uma gravidez ou se faz um } \\
\text { aborto, em todas as situações? } \\
\text { Totalmente ou em parte? }\end{array}$ & $\begin{array}{c}0,001 \\
(1.217)\end{array}$ & $\begin{array}{l}\text { - Concorda totalmente } \\
\text { - Concorda ou discorda em parte } \\
\text { - É indiferente (nem C nem D) } \\
\text { - Discorda totalmente } \\
\text { - Não sabe ou não respondeu }\end{array}$ & $\begin{array}{l}20,2 \\
27,1 \\
05,3 \\
45,4 \\
02,0\end{array}$ & $\begin{array}{l}23,9 \\
26,5 \\
04,2 \\
43,1 \\
02,2\end{array}$ & $\begin{array}{l}14,6 \\
28,0 \\
06,8 \\
49,0 \\
01,6\end{array}$ \\
\hline $\begin{array}{l}\text { Você concorda ou discorda da frase: "A } \\
\text { mulher é quem deve decidir como será o } \\
\text { trabalho doméstico, não importa quem } \\
\text { faça"? }\end{array}$ & $\begin{array}{c}0,007 \\
(1.239)\end{array}$ & $\begin{array}{l}\text { - Concorda totalmente } \\
\text { - Concorda ou discorda em parte } \\
\text { - É indiferente (nem C nem D) } \\
\text { - Discorda totalmente } \\
\text { - Não sabe ou não respondeu }\end{array}$ & $\begin{array}{l}41,7 \\
31,6 \\
06,7 \\
19,4 \\
00,6\end{array}$ & $\begin{array}{l}44,9 \\
30,6 \\
05,3 \\
18,2 \\
00,6\end{array}$ & $\begin{array}{l}37,1 \\
32,9 \\
08,7 \\
21,0 \\
00,2\end{array}$ \\
\hline $\begin{array}{l}\text { Você concorda ou discorda da frase: "É } \\
\text { principalmente o homem quem deve } \\
\text { sustentar a família"? }\end{array}$ & $\begin{array}{c}0,010 \\
(1.239)\end{array}$ & $\begin{array}{l}\text { - Concorda totalmente } \\
\text { - Concorda ou discorda em parte } \\
\text { - É indiferente (nem C nem D) } \\
\text { - Discorda totalmente } \\
\text { - Não sabe ou não respondeu }\end{array}$ & $\begin{array}{l}33,2 \\
33,3 \\
06,6 \\
26,3 \\
00,6\end{array}$ & $\begin{array}{l}30,6 \\
32,1 \\
06,8 \\
29,8 \\
00,7\end{array}$ & $\begin{array}{l}36,9 \\
35,1 \\
06,3 \\
21,2 \\
00,4\end{array}$ \\
\hline $\begin{array}{l}\text { Você concorda ou discorda da frase: "Os } \\
\text { homens, mesmo que eles queiram, não } \\
\text { sabem fazer o trabalho de casa"? }\end{array}$ & $\begin{array}{c}0,041 \\
(1.239)\end{array}$ & $\begin{array}{l}\text { - Concorda totalmente } \\
\text { - Concorda ou discorda em parte } \\
\text { - É indiferente (nem C nem D) } \\
\text { - Discorda totalmente } \\
\text { - Não sabe ou não respondeu }\end{array}$ & $\begin{array}{l}21,8 \\
36,5 \\
07,7 \\
33,1 \\
00,9\end{array}$ & $\begin{array}{l}23,9 \\
35,1 \\
06,4 \\
33,5 \\
01,1 \\
\end{array}$ & $\begin{array}{l}18,7 \\
38,5 \\
09,7 \\
32,5 \\
00,6\end{array}$ \\
\hline $\begin{array}{l}\text { Você concorda ou discorda da frase: } \\
\text { "Nas decisões importantes é justo que } \\
\text { na casa o homem tenha a última } \\
\text { palavra"? }\end{array}$ & $\begin{array}{c}0,000 \\
(1.217)\end{array}$ & $\begin{array}{l}\text { - Concorda totalmente } \\
\text { - Concorda ou discorda em parte } \\
\text { - É indiferente (nem C nem D) } \\
\text { - Discorda totalmente } \\
\text { - Não sabe ou não respondeu }\end{array}$ & $\begin{array}{l}15,4 \\
27,2 \\
06,2 \\
50,8 \\
00,4\end{array}$ & $\begin{array}{l}12,0 \\
22,2 \\
03,7 \\
61,4 \\
00,7\end{array}$ & $\begin{array}{l}20,6 \\
34,8 \\
09,9 \\
34,8 \\
00,0\end{array}$ \\
\hline $\begin{array}{l}\text { Você concorda ou discorda da frase: } \\
\text { "Para o casal é importante que o homem } \\
\text { tenha mais experiência sexual que a } \\
\text { mulher"? }\end{array}$ & $\begin{array}{l}0,000 * \\
(1.217)\end{array}$ & $\begin{array}{l}\text { - Concorda totalmente } \\
\text { - Concorda ou discorda em parte } \\
\text { - É indiferente (nem C nem D) } \\
\text { - Discorda totalmente } \\
\text { - Não sabe ou não respondeu }\end{array}$ & $\begin{array}{l}13,6 \\
23,1 \\
11,3 \\
49,8 \\
02,2\end{array}$ & $\begin{array}{l}12,7 \\
19,0 \\
08,3 \\
56,8 \\
03,1 \\
\end{array}$ & $\begin{array}{l}14,8 \\
29,2 \\
15,8 \\
39,3 \\
00,8\end{array}$ \\
\hline $\begin{array}{l}\text { Você concorda ou discorda da frase: "A } \\
\text { mulher casada deve satisfazer o marido } \\
\text { sexualmente mesmo quando não tem } \\
\text { vontade"? }\end{array}$ & $\begin{array}{l}0,000 * \\
(1.217)\end{array}$ & $\begin{array}{l}\text { - Concorda totalmente } \\
\text { - Concorda ou discorda em parte } \\
\text { - É indiferente (nem C nem D) } \\
\text { - Discorda totalmente } \\
\text { - Não sabe ou não respondeu }\end{array}$ & $\begin{array}{l}08,2 \\
15,0 \\
04,8 \\
71,2 \\
00,8\end{array}$ & $\begin{array}{l}06,6 \\
11,5 \\
02,9 \\
75,4 \\
01,0\end{array}$ & $\begin{array}{l}09,3 \\
20,4 \\
07,6 \\
64,8 \\
00,6\end{array}$ \\
\hline
\end{tabular}

Fonte: Microdados da Pesquisa "Mulheres brasileiras e gênero nos espaços público e privado" (Fundação Perseu Abramo e Sesc, 2010). Compilação própria.

Notas: Asymp. Sign./(N) = Asymptotic Significance e número de respostas. Nos resultados destacados na cor cinza foram encontradas diferenças estatisticamente significativas entre as categorias de resposta de mulheres e de homens, considerando o teste do qui-quadrado (Sign. $<$ ou $=0,05$ ) e o resíduo ajustado (Adjusted Residual $>$ ou $=2,0$ ). $*$ Adjusted Residual $<2,0$. 


\begin{abstract}
The symbolic reproduction of inequalities between women and men in Brazil

This article deals with collective representations (Durkheim, 1996) or social representations (Moscovici, 2003) with a gender perspective (Scott, 1986) on matters concerning the public and private spaces (Saffioti, 1999; Fougeyrollas-Schwebel, 2009). From compilation and analysis of data from the National Survey "Brazilian women and gender in public and private spaces", it was sought: a) to know the general diffusion of the representations; b) compare the feminine and masculine opinions, in their similarities and differences. The representations reinforce the role of women as responsible for reproductive and unpaid work and for men as providers of the home and active in public space, as demonstrated, for example, for the distrust manifested by the interviewees about the political-administrative capacity of women and the masculine ability in perform household chores.
\end{abstract}

Keywords: social representations; symbolic violence; gender; public space; private area

\title{
Resumen
}

La reproducción simbólica de desigualdades entre mujeres y hombres en Brasil

Este artículo trata sobre representaciones colectivas (Durkheim, 1996) o representaciones sociales (Moscovici, 2003) con una perspectiva de género (Scott, 1986) sobre asuntos relacionados con los espacios públicos y privados (Saffioti, 1999; Fougeyrollas-Schwebel, 2009). A partir de la organización y el análisis de datos de la Encuesta Nacional "Mujeres brasileñas y género en los espacios público y privado", se anheló: a) conocer la difusión general de las representaciones; b) comparar las opiniones femeninas y masculinas, en sus semejanzas y diferencias. Las representaciones refuerzan el papel de la mujer como encargada del trabajo reproductivo y no remunerado y del hombre como proveedor del hogar y actuante en el espacio público, como lo demuestra, por ejemplo, la desconfianza manifestada por los entrevistados sobre la capacidad político-administrativa de las mujeres y sobre la habilidad masculina en realizar tareas domésticas. Palabras clave: representaciones sociales; violencia simbólica; género; espacio público; espacio privado

\section{Résumé}

La reproduction symbolique des inégalités entre les femmes et les hommes au Brésil

Cet article analyse des représentations collectives (Durkheim, 1996) ou sociales (Moscovici, 2003) avec une perspective de genre (Scott, 1986) sur des questions concernant les espaces publics et privés (Saffioti, 1999; Fougeyrollas-Schwebel, 2009). À partir de la compilation et de I'analyse des données de l'enquête nationale "Les femmes brésiliennes et le genre dans les espaces publics et privés", on a cherché: a) à connaître la diffusion générale des représentations; b) comparer les opinions féminines et masculines, dans leurs similitudes et leurs différences. Les représentations renforcent le rôle des femmes en tant que responsables du travail reproductif et non rémunéré et des hommes en tant que pourvoyeurs de domicile et actifs dans l'espace public, comme le montre, par exemple, la méfiance exprimée par personnes interrogées sur la capacité politico-administrative des femmes et sur la capacité masculine à effectuer des tâches ménagères. Mots-clés: représentations sociales; violence symbolique; genre; espace public; espace privé

Artigo submetido à publicação em 2 de junho de 2018. Artigo ressubmetido à publicação em 12 de junho de 2019. Versão final aprovada em 15 de junho de 2020.

Opinião Pública adota a licença Creative Commons CC-BY. 